This item was submitted to Loughborough's Research Repository by the author.

Items in Figshare are protected by copyright, with all rights reserved, unless otherwise indicated.

\title{
Historical and existential coherence in political commercials
}

PLEASE CITE THE PUBLISHED VERSION

https://doi.org/10.1177/1750481317707560

PUBLISHER

SAGE $\odot$ The Authors

VERSION

AM (Accepted Manuscript)

\section{PUBLISHER STATEMENT}

This work is made available according to the conditions of the Creative Commons Attribution-NonCommercialNoDerivatives 4.0 International (CC BY-NC-ND 4.0) licence. Full details of this licence are available at: https://creativecommons.org/licenses/by-nc-nd/4.0/

\section{LICENCE}

CC BY-NC-ND 4.0

\section{REPOSITORY RECORD}

Meade, Melissa R., and Jessica Robles. 2019. "Historical and Existential Coherence in Political Commercials". figshare. https://hdl.handle.net/2134/24893. 


\section{Running Head: HISTORICAL AND EXISTENTIAL COHERENCE}

Historical and Existential Coherence in Political Commercials

Author: Melissa R. Meade

Affiliation: Temple University

E-mail address: melissa.meade@ temple.edu

Author: Jessica S. Robles

Affiliation: Loughborough University

E-mail address: j.j.robles@lboro.ac.uk

Article Size: Words (excluding cover sheet) $=11695$

\section{Autobiographical Notes}

Melissa R. Meade is a doctoral candidate in Media and Communication at Temple University in Philadelphia. She has taught at Instituto Tecnológico y de Estudios Superiores de Monterrey (ITESM), Mexico, University of the Arts, Philadelphia, and Temple University. Her research sits at the intersection of media, identity, and memory and explores the experience of marginalized people and their cultural production. Her dissertation uses online and offline ethnographic approaches to understand the upheavals of deindustrialization on struggling former coal-mining towns in northern Appalachia. She is the author of 'In the Shadow of the Coal Breaker: Cultural Extraction and Participatory Communication in the Anthracite Mining Region,' Cultural Studies (in press). Her essay 'Latrinalia in a Room of One's Own: Language, Gender, and Place' is in the volume The Materiality of Graffiti: Studying and Understanding Graffiti from Prehistory to the 21st century. She was the recipient of the Donald P. Cushman Memorial Award from the National Communication Association.

Jessica S. Robles (PhD, University of Colorado at Boulder) is a lecturer in Social Psychology in the Department of Social Sciences at Loughborough University, UK. She has taught at the University of Colorado, the University of New Hampshire, and the University of Washington. Her research takes a discourse analytic approach to how difference is socially organized and morally valenced in everyday interactions. She recently coauthored the second edition of the book Everyday Talk: Building and Reflecting Identities with first author Karen Tracy.

\section{Acknowledgements}

The authors thank the reviewers for their valuable feedback on this manuscript, and thank the editor for his patient support.

\section{Declaration of conflicting interests}

The authors declared no potential conflicts of interest with respect to the research, authorship, and/or publication of this article.

\section{Funding}

The authors received no financial support for the research, authorship, and/or publication of this article. 


\begin{abstract}
This article analyzes discourse, narrative, and video editing to introduce the concept of "historical coherence." This concept is an expansion on Alessandro Duranti's notion of “existential coherence" - the construction of an embodied narrative connecting a candidate's past with his/her decision to run for office - from his 2006 study of a candidate's campaign speeches. The present study examines how language and communication are linked with historical narratives through the use of a multimodal stories in which US political commercials link candidates' present actions with historical events, dynamics, artifacts and/or figures. This "historical coherence" is constructed through several strategies: (1) constructing a narrative in which popular historical figures or archetypal figures are in agreement with the candidate; (2) preempting charges of lack of historical coherence; (3) presenting historical restrictions to freedom and casting the candidate, or the candidate's party in general, as a preventative from future calamities and transgressions to freedom.

\section{Keywords}

Narrative coherence, multimodality, discourse analysis, political commercials, video analysis, historical coherence, existential coherence, super PACs
\end{abstract}




\section{Historical and Existential Coherence in Political Commercials}

Political messaging positions a candidate within a recognizable narrative structure, linking her or him with an ideologically coherent world-view. The "'message' is the characterological aura of a persona ... who has not only said and done things, but has the potential [to act] in certain ways" (Silverstein, 2011: 204). Political advertising therefore sells a person - a person who is meant to capture an ideological position with which viewers will identify. In order to present this ideological position in a meaningful way, political commercials deploy elements of communication such as speech and body language linking language to candidates' past, present, or future actions.

This article examines multimodal strategies used in political commercials to create "historical coherence" through talk, text, images, and editing techniques that construct a narrative resonance between a candidate's persona and interpretative patriotic histories, as well as preempting possible challenges to that coherence. Expanding on Duranti's (2006) concept of existential coherence, this analysis presents how Duranti's approach can apply to other types of political discourses, can draw on multimodal analysis, and can link up to other forms of continuity and coherence in discourse.

We begin by discussing literature on political messaging and existential coherence, followed by a description of methods. We present an analysis of three political commercials to illustrate the following historical coherence-building strategies: (1) constructing a narrative in which popular historical or archetypal figures are in agreement with the candidate; (2) preempting charges of lack of historical coherence; (3) presenting historical restrictions to freedom and casting the candidate, or the candidate's party in general, as a preventative from 
future calamities and transgressions to freedom. We end the paper by considering the implications of these results.

\section{Political messaging}

US political commercials, as a register of political messaging, are multimodal texts that make use of and combine multiple semiotic modes. Mode is defined here as "semiotic resources which allow the simultaneous realisation of discourses and types of (inter)action" (Kress and Van Leeuwen, 2001: 21). Because language is one mode among many that can be involved in communication (Kress and Van Leeuwan, 2001; Norris, 2004; Kress, 2009; Unsworth and Cléirigh, 2009), mode enriches meaning through culturally and socially-saturated representations (cf. Matthiessen, 2007) by using different communicative elements such as images, writing, layout, speech, gesture, and sound. As such, political commercials often display formal montage sequences adopted from early filmmaking ${ }^{1}$ by juxtaposing images to create subtle and not-sosubtle messaging. Together, these forms of discourse encode the message carrying a semiosis that links particular signifiers to implicit signified ideologies (Barthes, 1957/1972).

In the United States, the public receives a significant amount of information about political candidates through political commercials, which often are under the control of the candidate or her/his supporters; no other country has embraced this political communication tool more than the US (Kaid and Davidson, 1986). Such commercials represent the most expensive aspect of most political campaigns and have become the primary communication tool between candidates and publics (Kaid, 2006)

Political language in general can persuade a public to take credence in a speaker's worldview and proposals (Vesnic-Alujevic, 2011; Duranti, 2006). However, commercials are

\footnotetext{
${ }^{1}$ See Sergei Eisenstein (1949) for a discussion of montage.
} 
made up of media language and presentations that are not transparent representations of the world, but rather the result of practices and techniques used to produce them (see Fairclough, 1998). A television commercial is both a visual and auditory medium, and production techniques are used to modify verbal and nonverbal content. As such, these elements should be considered in conjunction when analyzing political advertising. In the process of elections, speech and other modalities are grouped together into "usable constituents of campaigns of personal identity and identifiability" (Silverstein, 2011: 205), thereby distinguishing candidates' identities by the kinds of narratives they produce. In other words, political commercials tell a story that persuasively configures semiotic resources through multiple modes to craft a candidate's persona and the ideology for which it stands.

US political parties and organizations take advantage of political commercials to endorse their candidates. In the 2010 US Supreme Court Citizens United versus the Federal Election Commission ruling, the government lifted restrictions on how much money corporations, unions, and individuals can spend on federal political advertisements, therefore making it more urgent for the public to consider how language and production techniques work together to create meaning - perhaps especially when political advertisements are produced by outside groups allegedly without the knowledge of the candidate. This ruling engendered the proliferation of PACs, or political action committees, which collect campaign donations from their members and apply the funds either directly to campaigns or to the creation of their own media (in favor of or against candidates or legislation). Super PACs may raise and spend unlimited money independently to support or oppose candidates and consequently have no legal limit on donation size (cf. Graham, July 16, 2015). 
By institutionalizing the notion of the political commercial as speech, this Citizens United ruling has literally decided that the money that finances political commercials and advertisements is a form of free speech. This "speech" is now protected by the US First Amendment and includes political commercials about candidates allegedly not funded by the candidate, but rather by these PACs (such as the one supporting Hillary Clinton examined in this paper). Yet the often unclear genesis of PAC funding and relative ambiguity to the viewer as to the progenitor of the commercial - the candidate directly or a PAC - adds another complex discursive layer to the landscape of political speech. Moreover, the candidate's network of support is spread out into PACs, which have unofficial dotted lines to candidates' interests.

To gain an understanding of this rich milieu, any "analysis ... has to be in a context, and ... in the analysis of both the verbal and the visual modes context has to play its part" (Wekesa, 2012: 225). As such, this paper examines the relationship of language to various forms of multimodal discourse (e.g. video techniques, embodiment practices, sound, and mise-en-scène) in Tea Party discourse, including one candidate's set of political commercials, as well as a super PAC's commercial advocating Hillary Clinton, 2016. The commercials investigated were selected for their different backgrounds based on the following three criteria: They offer ideologically distinct political discourses; one represents a local candidate whereas the other depicts a national candidate; and finally, they were funded and produced through slightly different mechanisms. The Tea Party candidate was a 2010 US Congressional Republican primary candidate and an affiliate of the Tea Party in Alabama's second district. He raised limited funds, yet most of the funds were raised from larger donors who gave $\$ 200$ or more and some of his donors were PACs. The Tea Party is a US political movement that staged protests and endorsed candidates after the election of US President Barack Obama in 2008. These Tea 
Party political advertisements represent a case in point of a local candidate who received donations for his campaign and applied them to the its production, while the samples of data from the political commercials released by the super PAC for Hillary Clinton 2016 illustrate how this discourse is synchronically coherent with other national political discourses. We put these data side-by-side in our analysis to show how historical coherence can function ideologically across forms of political commercials.

\section{Existential and historical coherence in political narrative}

This study examines how political commercials use techniques of coherence that build a narrative presenting a political candidate as a certain character consistent, with an implicit ideology, whose past actions connect to his or her campaign. We extend the work of Duranti (2006) who followed one political candidate and applied language analysis to campaign speeches, debates, and press conferences. Through his analysis, he argued that a candidate develops "existential coherence" (Duranti, 2006: 472) by integrating past, present, and future actions to create a moral logic substantiating her or his run for office or particular stance on an issue. This kind of coherence has a moral dimension or "radical reflexivity" (Taylor, 1991 as noted in Duranti, 2006: 470) insofar as a candidate asks herself or himself - through words and actions - if s/he is both the person s/he desires to be and the person s/he promised to be. Through this reflection, candidates present and attempt to embody their notion of an ideal candidate in public settings.

The current study of political commercials analyzes the multimodality of the discourse employed by studying linguistic and embodied practices alongside video and sound techniques. This analysis shows multimodal political communication embedded with ideas of the candidate's existential coherence, but it extends Duranti's approach to introduce a new type of coherence 
developed in this paper: historical coherence. Historical coherence is created by linking a candidate with familiar historical events and/or by linking their actions with those of historical figures or archetypes to construct a consistency between persons then and now. Whereas in existential coherence a candidate's personal actions from the past are linked with present and future actions, historical coherence links the candidate directly with particular versions of history to show that the candidate's words and actions are congruent with those of popular or wellknown historical, archetypal, or stereotypical figures. The figures operate as semantic parts that relate coherently (metonymically, synecdochally) to a whole historical and cultural narrative context (van Dijk, 1980), with various semiotic strategies deployed to reinforce the resonance and continuity between the part and the whole, the moment and the past. Both kinds of coherence (existential and historical) thereby create a moral logic supporting the candidate's decision to run for office.

Historical and/or existential coherence supports the narrative. The candidates, through their speech and embodied practices, make connections and allusions. They produce or are featured in media that rely on images and sounds used to create the character in the plot. These media subsequently circulate tropes about this character. The character is created by the rehearsal and reiteration of this narrative. These media create a reverberation in the public making aspects of candidates' historical and existential identities salient.

\section{Methods}

We use discourse analysis informed by "political discourse analysis" (van Dijk, 1997: 11) to consider contextual dimensions, discourse properties, and discourse structure to examine three political commercials: "Gather Your Armies" (1:03) and "Slavery" (2:30), both produced by Rick Barber for Congress in Alabama's Second Congressional District; and "Stand with Hillary" 
(3:23), produced by the super PAC Stand with Hillary 2016. These videos were selected to highlight that ideologically distinct political discourses still exhibit both types of coherence advanced in the present paper-existential and historical coherence. We also illustrate how the ideologies constructed through the commercials resonate with other political discourses by considering briefly some quotations from other candidate media including speech and social media. We focus on multimodality in political commercials, but we also suggest that these examples are instantiations of larger ideological discourses indexed by certain semiotic and narrative devices.

The commercials are also situated at key historical moments: the rise of a party heralding a resurgence of far-right politics on one hand, and the ramping up of the campaign for a female presidential candidate for an upcoming election, on the other. Yet the commercials represent interesting nuances in the funding strategies used, thereby touching upon important considerations for the role of candidate funding and support in the domain of political commercials.

To collect the data, each video was downloaded from YouTube and the speech was transcribed using the transcription conventions featured in Appendix A developed by Sacks, Schegloff, and Jefferson (1974). The video-style techniques were transcribed using the transcription conventions that we introduce in Appendix B that we hope can be useful to researchers who wish to do this kind of analysis. Thus the text of the commercials has been transcribed considering not only verbal communication, but also embodiment practices and video-style and film techniques. Discourse analysts have increasingly acknowledged the importance of examining a wider range of semiotic resources used in interaction, including gesture and embodiment, spatial organization, object manipulation, etc. (e.g., Goodwin, 2007; 
Kress and Van Leeuwen, 2001). Furthermore, in transcribing and analyzing communication in political commercials, embodied behavior is usually planned for in advance. Likewise, the creators of commercials use film techniques such as editing, lighting, mise-en-scène elements, and cinematography to accompany, construct, and/or emphasize what is said. Therefore, this analysis presupposes that in transcribing and analyzing communication in mass media, both language and embodied behavior should be considered in conjunction with the video-style and film techniques used. The video-style transcript that accompanies this paper includes documentation of video-style techniques. Appendix A includes some shorthand that can be used to create such a transcript.

Film scholar Timothy Corrigan (2011) has noted that "[f]ilm technology, production, and distribution are commercial and economic enterprises" (20). Drawing from this assertion we propose that US political commercials are a kind of high budget political speech: the more money a candidate has, the more sophisticated production his or her commercials can display. Likewise, the lower budget commercials can function as a political sign indexing a candidate's limited funds. These displays of production skills could have implications for the persuasiveness to audiences; for example, a higher budget may yield a more aesthetically pleasing result, whereas a lower budget may signal a form of authenticity. Also, more funds can equal more speech, especially in the larger milieu of Citizens' United. A candidate who has PACs' support may buy speech and counter other candidates' messages by saturating their candidate's narrative on assorted media platforms while negating the narratives of the opposition.

In the following analysis, we begin by showing how existential coherence can be gleaned from an analysis of multimodality in commercial production techniques. We follow by focusing on three strategies that achieve what we call historical coherence: (1) constructing a narrative in 
which popular historical figures or archetypal figures are in agreement with the candidate; (2) preempting charges of lack of historical coherence; and (3) presenting historical restrictions to freedom while casting the candidate, or the candidate's party in general, as a preventative from future calamities and transgressions to freedom. We discuss how these strategies support implicit ideologies regarding persuasive American ideals around the concept of freedom.

\section{Candidate's existential coherence}

"An oath to defend that with my life"

The first ad in a set of locally-aired Republican primary commercials for Tea Partyendorsed candidate Rick Barber of Alabama's Second District uses the technique of narrative construction involving existential coherence. A candidate may integrate past, present, and future actions in order to create a logic justifying her or his run for office or stance on an issue (Duranti, 2006). One's continuity of character is developed by (1) demonstrating that things have not changed over time; or (2) demonstrating that change continues to support the continuity of some other feature - for example, there is a higher logic that compels the change (Duranti, 2006). In this section we discuss how existential coherence is accomplished through multimodal techniques in examples from political commercials.

One particular narrative strategy involves invoking the present as a natural outcome of the past. The gist of this strategy shows the candidate entering politics as an extension of his or her other life work and activities. In the first video analyzed entitled "Gather Your Armies", Rick Barber, while talking with the actors dressed as patriots, presents his decision to run for Congress (in line 8) as an extension of his "oath to defend that" with his life-a deictic reference he makes while pointing at a copy of the US Constitution. The camera work, editing, and props emphasize 
a relationship between him and the Constitution that he establishes through language and body movement.

Barber presents his marine experience as one of the past experiences that has better prepared him for office. In fact, as he confers with the founding fathers, he connects his marine legacy to his statement "I can't stand by while these evils are perpetrated." As he utters the entire sequence in line 8: "Now I took an oath to defend that with my life. And I can't stand by while these evils are perpetrated," he raises his volume at the end of the utterance. The sequence begins with the camera panning to a medium shot of Barber in which he points to a document on table; the camera pans to a medium close-up of his hand. It is a copy of the US Constitution. Behind it, the table is covered with the red and white stripes of the US flag. (See Figure 1). The camera cuts to a medium close-up of the candidate as his volume increases. According to this sequence, the candidate is a former marine whose decision to run for office is an extension of his inextricable link to the Constitution. He is even conversing with the founding fathers at a table adorned with red and white stripes. The entire semiotic field is saturated with representations of this extension.

In another instance in line 2, Barber says "Some of your men own taverns. Sam, you were a brewer; Mr. President, a distiller. You know how tough it is to run a small business without a tyrannical government on your back." Barber is establishing his connection to the patriots as business owners. He is a small business owner, so logically, like the founding fathers, his present is an extension of the past. Once again, the video style assists in driving this language home. He wears everyman's attire — a red and blue plaid button-down shirt with a white undershirt sticking out. Not only do his words and attire suggest the connection between the past and present, but there is also hand-held camera motion, which provides a more real, documentary, or an unrehearsed cinéma vérité style as opposed to a stationary camera that sits on 
a tripod. Moreover, if campaign funding is now considered a type of political speech, the handheld camera movement signifies the candidate's lower budget; this signification can be either intentional or the result of actual prohibitive production costs.

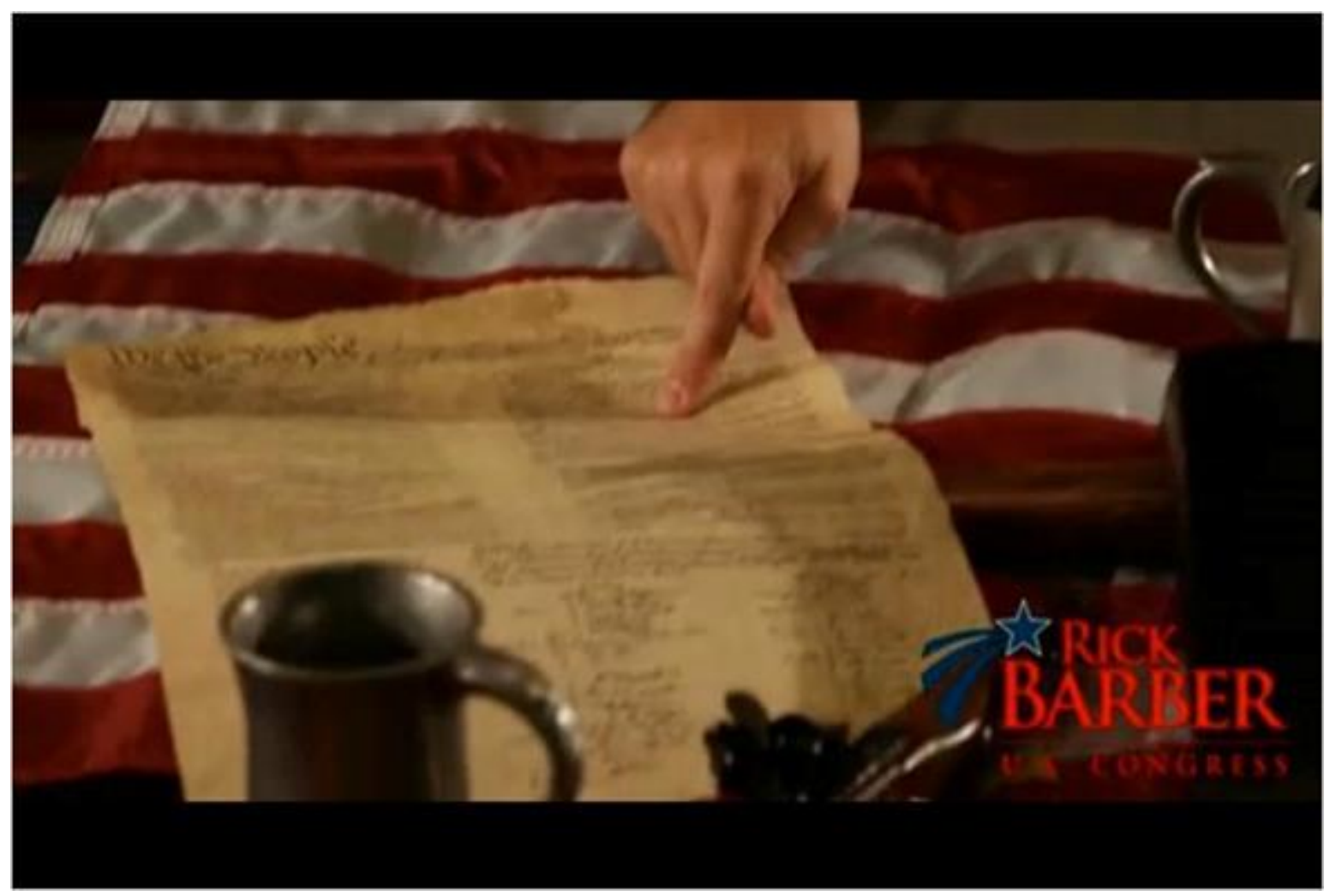

Figure 1. Barber demonstrates the embodied practice of pointing to the US Constitution, which sits on a table adorned in US flag imagery. Addressing characters dressed as the "founding fathers" and American revolutionaries, Barber references his past work as a marine as having better prepared him for office and points at the US Constitution on the table as he utters the words 'Now I took an oath to defend that with my life. And I CAN'T STAND BY WHILE THESE EVILS ARE PERPETRATED." The camera pans in to a medium close-up of his hand. The table is covered with the US flag and a pistol flanks the Constitution.

Note. From "Gather your armies" by Rick Barber for Congress

"A mother, a daughter, and through it all she's a loving wife"

Existential coherence is visible in other forms of the political commercial genre, and does not apply only to a particular political ideology (such as "conservative," "liberal," "republican," or "democrat"). "Stand with Hillary" is a commercial released by a super PAC of the same name. 
Although the commercial was not endorsed by Hillary Clinton directly_-“"campaigns' are in practice intricate constellations of political committees, super PACS and tax-exempt groups, engineered to avoid fund-raising restrictions imposed on candidates and their parties"

(Confessore and Lichtblau, May 17, 2015). Super PAC commercials then are in part ways to exploit loopholes and buy more political speech for candidates in the post-Citizens United era. Candidates can openly raise money for the super PACS as long as they are not the one asking for the money.

Against this backdrop, a study of "Stand with Hillary" is poignant because of the timing of its release in early 2015, before primary season. In particular, the commercial is one in which Clinton's existential coherence as a woman seeking to be the first female US President is constructed by a male cowboy archetype. In the video, the cowboy sings a country song in support of her candidacy, and images of Clinton and her family are juxtaposed with images of people working in labor, with a cowboy who later smashes a glass ceiling, with images of the cowboy's family, and with general symbols of the cowboy, such as close-ups of his boots. The chosen musical genre for the video — country music — is one dominated by white males and thereby links Clinton with these voters. As the cowboy sings the words 'I been thinkin' about one great lady like the women in my life. She's a mother, a daughter, and through it all she's a loving wife," images of the cowboy with his wife and daughter are depicted in a montage next to images of Clinton with her daughter, and husband, former President Bill Clinton. (See Figure 2). The juxtaposition of the images along with the lyrics suggests that Clinton is a great American story - a woman who is a family woman like the cowboy's wife. Together the narrative created can be both reassuring - like the mother or wife as the embodiment of traditional female rolesand also motivating (to daughters) as a role model. 

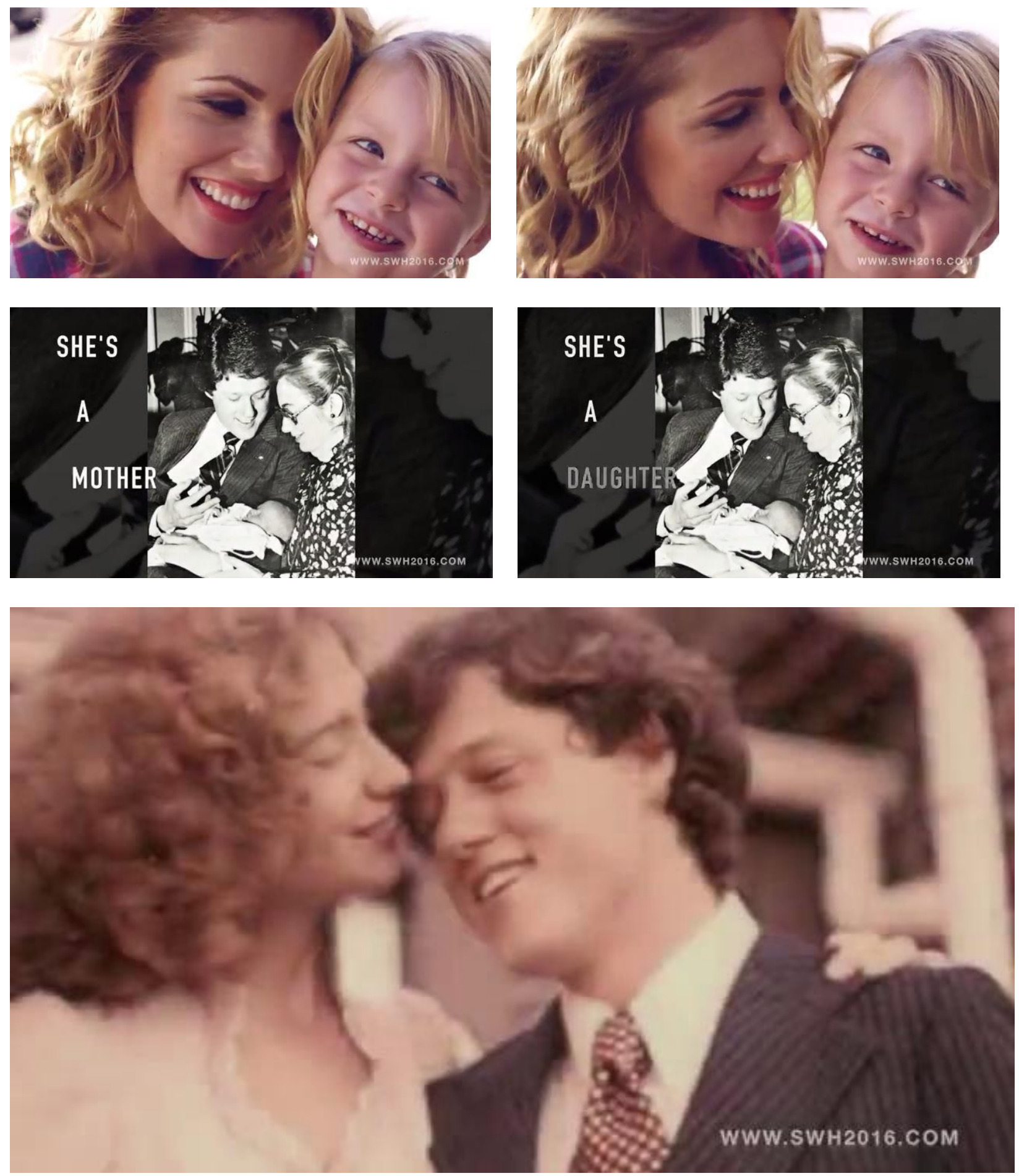

Figure 2. The montage sequence juxtaposes images of the cowboy's wife engaged in loving family activities with those of Hillary Clinton engaged in similar activities.

Note. From "Stand with Hillary" by Stand With Hillary 2016 
This example also shows how existential coherence may be constructed not just by an individual, but for an individual, as in commercials like this, which are not directly sponsored by the candidate. However, it resonates with the way Clinton positions herself existentially. In the first 2016 Democratic debate, Hillary Clinton differentiated herself from other candidates during the two-minute introduction by focusing on her story and creating existential coherence — she is a family woman with working-class roots, a grandmother, but also an experienced candidate. She used these experiences to show that she wants the same opportunities for children across the nation as she wants for her grandchild:

I'm Hillary Clinton. I have been proud and privileged to serve as first lady, as a senator from New York, and as secretary of state. I'm the granddaughter of a factory worker and the grandmother of a wonderful one-year-old child. And every day, I think about what we need to do to make sure that opportunity is available not just for her, but for all of our children. I have spent a very long time - my entire adult life - looking for ways to even the odds to help people have a chance to get ahead, and, in particular, to find the ways for each child to live up to his or her God-given potential.

Although opponent Senator Webb also detailed his family history during the introductions at the debate, he did not weave it into the type of narrative Clinton constructed. He explained his background and the jobs of his children, but in Clinton's narrative she connected family and country, arguing that those experiences have equipped her to lead all families to a better place.

In the commercial examined here, the cowboy uses a similar narrative to the one Clinton established for herself, though the implications may be more implicit. The cowboy croons, "Oh, there is something about her ... this great lady. Caring, hard working, once a first lady. She fights for country and my family. Now it's time for us to stand up with Hillary." The singer makes the case for Hillary — she is feminine enough, family-oriented, and she can also fight for her country and for others' families. Here Hillary is being praised for having done her time in more 
stereotypically nurturing roles. Thus, the cowboy crooner preempts charges that Hillary has not occupied so-called traditional roles. Republican candidates have often attacked Clinton for her active political career. For example, "Pat Buchanan sneered at Hillary Rodham Clinton's advisory role during her husband's campaign, bringing up her profession as if it were an indictment: 'Elect me, and you get two for the price of one, Mr. Clinton says of his lawyerspouse"” (Daughton, 1994: 116). The cowboy protagonist makes the case for Hillary's gendered existential coherence aided by props and facilitated by editing techniques. He is standing in front of barn donning a cowboy hat and then the video cuts back to the singer and his group playing in front of an American flag. The symbolism asks the viewer to understand the narrative as a great American narrative.

As the commercial wraps up, the cowboy stands by his red pickup truck, which has run out of gas, and a motorcycle pulls up. The motorcycle driver has a helmet on, but the cowboy tips his hat. The driver takes off the helmet, and it is the cowboy's wife who is the motorcycle driver. He gets on the back and she drives off with him after they exchange warm smiles. The video-style again preempts challenges to femininity and family values common in US political discourse and in particular those directed at Hillary Clinton by showing the woman in the driver's seat — not of any vehicle, but of a motorcycle, which takes substantial upper-body strength to hold up. The gender binary or the narrowly-defined dichotomous masculine and feminine features that support unequal gender relations is challenged by the video-style techniques that reveal the initially gender-ambiguous driver of the motorcycle as female. The cowboy's wife as agent-subject and the cowboy smile and drive off into the distance tying Clinton with the natural and relaxed power displayed by having the female in the driver's seat. 
These examples illustrate some of the ways in which existential coherence is accomplished using multimodality in political commercials and how ideological narratives can be present across political genres, modes of discourse, and political categories. The next sections examine in more detail a form of coherence that extends beyond the particular candidate, creating a broader cultural and political narrative within which to situate candidacy.

\section{Historical coherence}

Here we extend Duranti's (2006) articulation of existential coherence as a narrative strategy that constructs a candidate's decision to run for office as a natural extension of his or her past by offering the concept of historical coherence. Historical coherence means that candidates are linked to renowned or infamous historical events and their present actions are tied to those of popular historical figures, archetypes, or tropes throughout a narrative. Coherence is established by demonstrating continuity over time. In the political commercials studied here, multimodal discourse such as images, gestures, montage sequences, and sound assist in creating this historical coherence. Both of the commercials representing Alabama Republican Tea Party candidate Rick Barber, "Gather Your Armies" and "Slavery" use this strategy, reinforcing Barber's language by video style techniques such as editing/montage sequences, volume increase, and various elements of mise-en-scène. In contrast to Duranti's (2006) work with live speeches delivered by candidates, it is assumed that Barber and his supporters were able to plan both of these commercials in great detail. Both commercials show the candidate speaking with actors portraying beloved deceased Presidents and other patriots. (See Figure 3). In the "Gather Your Armies" advertisement, the candidate focuses on the topic of taxes with the historical figures, which he connects to the Boston Tea Party discussed in the next section. 
As in the case of Barber's commercials, the commercial representing Hillary Clinton positions the then-Democratic candidate in a historical narrative, but this time it is cowboy who ushers in a female candidate's frontier-conquering leadership, literally smashing the glass ceiling for Clinton. The cowboy myth was crucial in building a sense of nationalism in post-Civil War America (Lewis, 1955), in particular because his geographical location was in the West, a neutral space in the War (Moskowitz, 2006). It is this archetype of white, American manliness who calls the troops: "Guys, put your boots on and let's smash this ceiling" for Hillary.

In both cases, the decision to run for office is constructed as historically logical or as a kind of Gramscian "common sense" (1971/2010: 197)—part of a larger patriotic narrative that draws on iconic, nostalgic images from the United States' past. The next section examines more closely how a narrative is populated by historical and archetypal figures presented as agreeing with (indeed, perhaps endorsing) the candidate.

\section{Creating a historically coherent narrative}

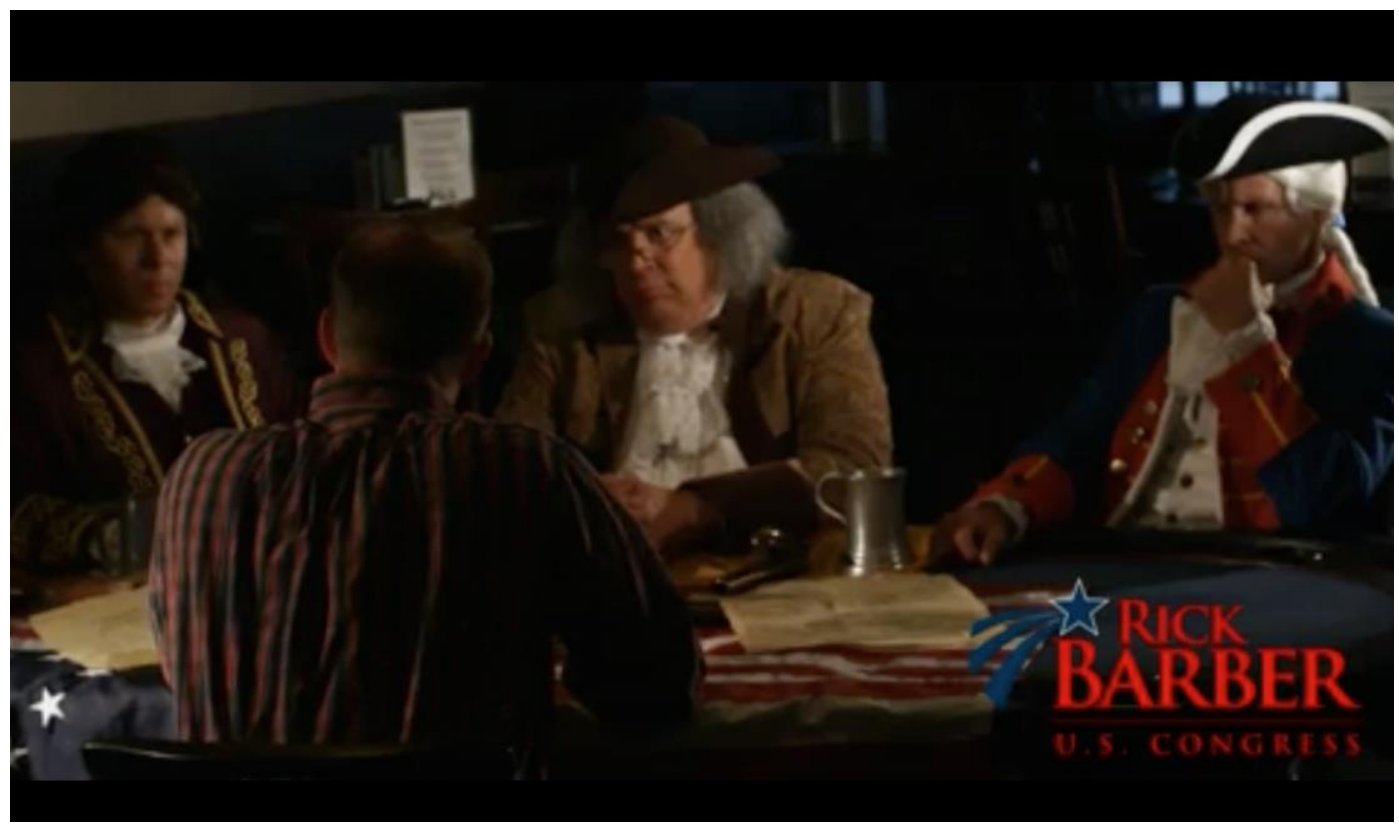

Figure 3. Barber creates historical coherence by positioning himself amongst the Patriots visible in this medium-long shot. 
Note. From "Gather your armies” by Rick Barber for Congress

In "Gather Your Armies," Barber positions the revolutionary forefathers in agreement with him. After speaking about taxes, in line 4 he says "Every year, if not every quarter, we're basically required to spy on ourselves." He precedes this comment with the phrase "You'll love this." These words spoken quickly and sarcastically suggest that the revolutionaries identify with Barber's position. Here, Barber's language is accompanied by a series of abrupt filmic cuts that switch from a medium shot of the candidate to an extreme close up and back, and then to a jump cut of an image of a character representing Ben Franklin. (See Figure 4).
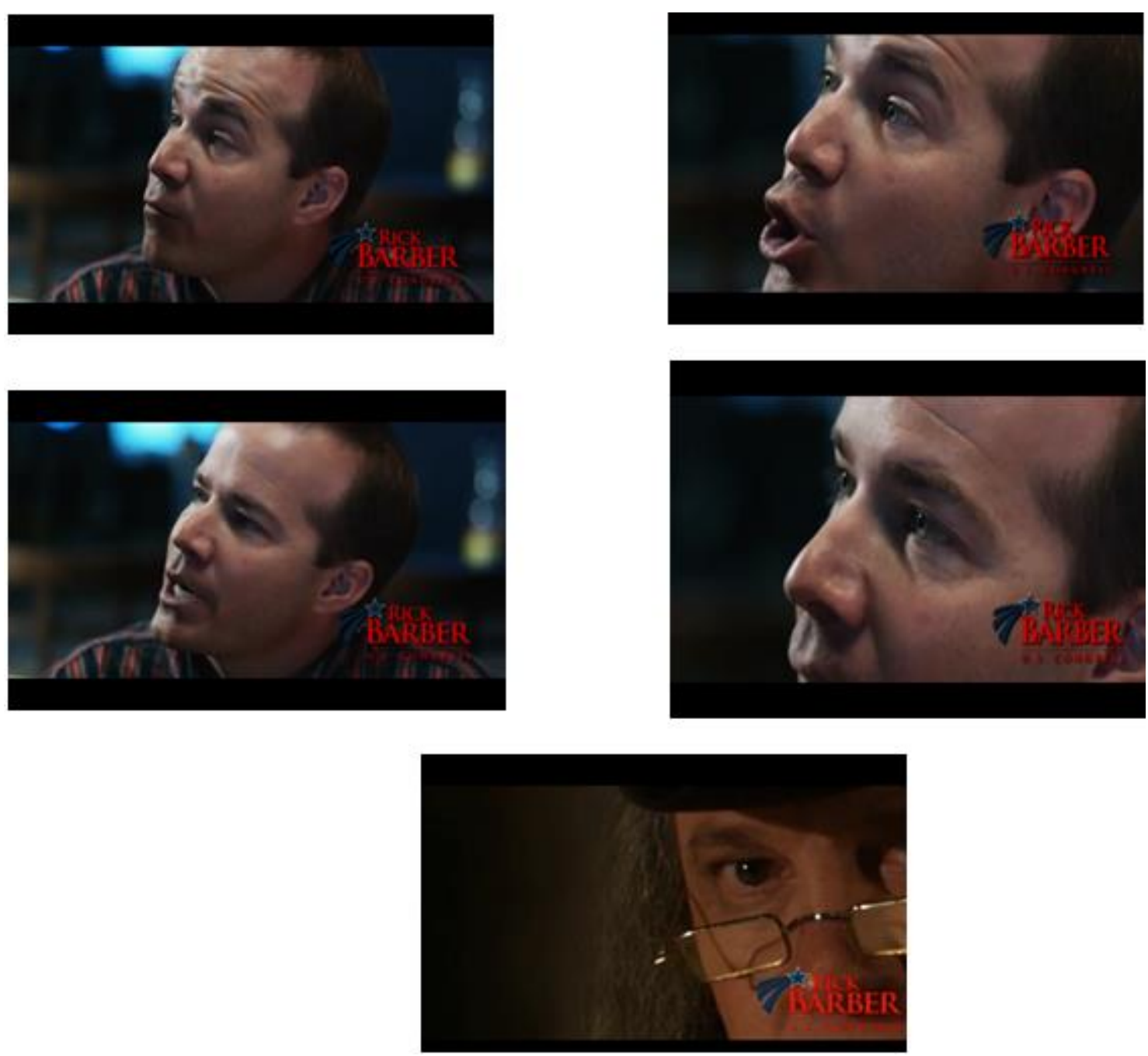

Figure 4. Barber's language is emphasized by a series of abrupt filmic cuts and a jump cut to an image of Ben Franklin. 
Note. From “Gather your armies” by Rick Barber for Congress.

This advertisement is undergirded by discourse about the Boston Tea Party. First, when Barber says the words "malicious audits," the camera pans to the various props on the table and focuses on an ever-present revolutionary era pistol on the table in an extreme close-up. (See Figure 5). As the transcript indicates, the camera then pans to a medium close up of a hand costumed in revolutionary attire, impatiently tapping fingers.

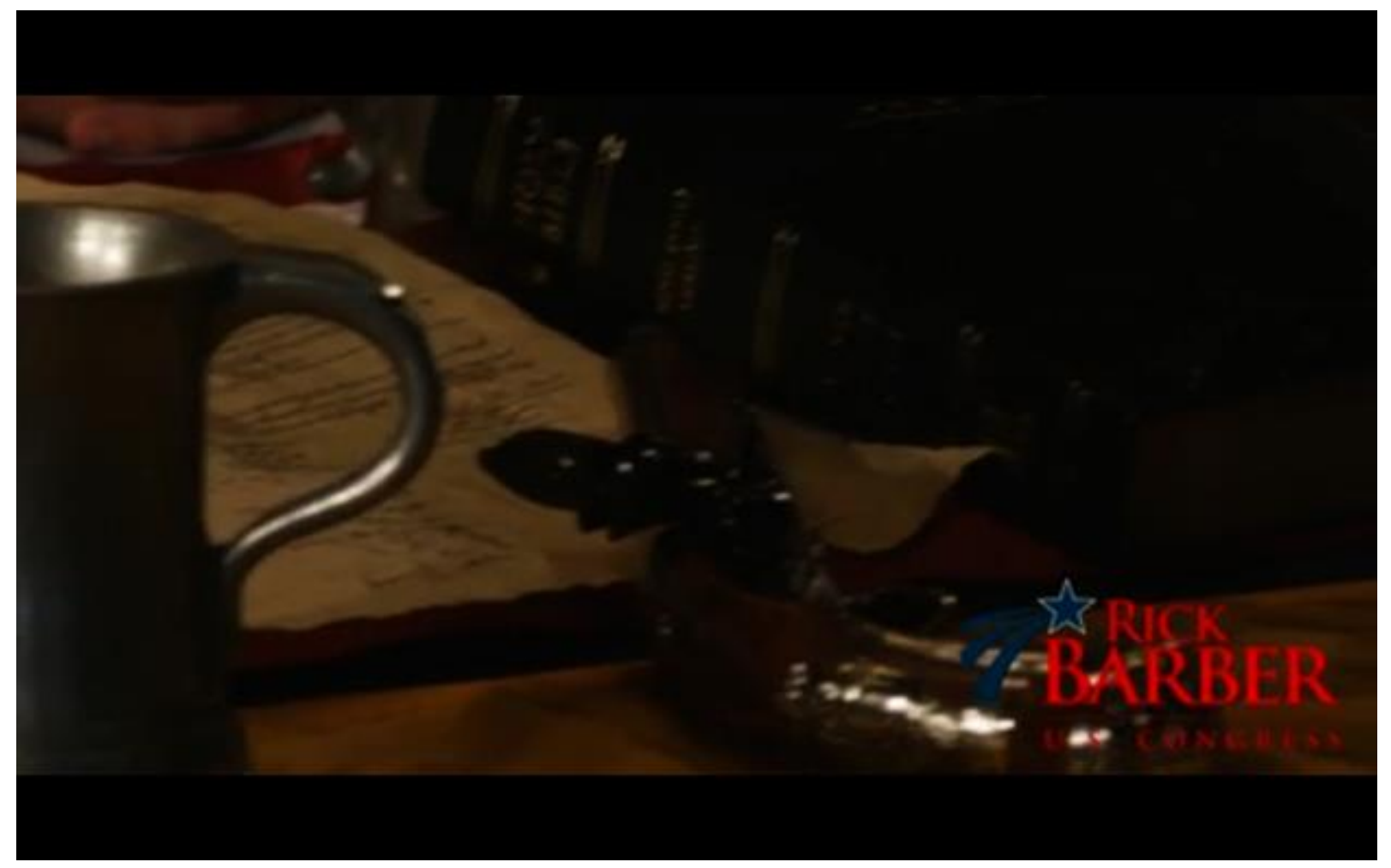

Figure 5. The camera pans to various props on the table and focuses on a revolutionary era pistol on the table at the point in which the candidate says "malicious audits."

Note. From "Gather your armies” by Rick Barber for Congress.

This ad presents an us/them orientation in line 3 when Barber says: "Today, we have an internal revenue service that enforces what they call a progressive income tax." Barber refers to the IRS as "they." "They" are clearly not representative of Barber and the revolutionaries. He 
strengthens his point later in line 9 when he says: "You gentlemen revolted over a tea tax - A TEA TAX! NOW LOOK AT US.” Earlier, Barber used language reminiscent of the Boston Tea Party when, in line 6 he says: "Without representation they could increase taxes, add costly regulations, or perform malicious audits." The Boston Tea Party was about the right to be taxed by a government with elected representation of the taxed citizenry. However, in the modern United States, citizens of all fifty states have an opportunity to vote and when taxed, are taxed with representation. In contrast, the colonists who dumped tea into the Boston Harbor objected to laws imposed upon them by government officials whom they had no voice in choosing (Larabee, 1979), hence the well-known American revolutionary expression Taxation Without Representation is Tyranny. By (mis)appropriating the name and language of the Boston Tea Party, Barber positions himself as a figure who could prevent historically tyrannical taxation without representation. Through this positioning, Barber's historical narrative gains coherency, demonstrating that he seeks office to prevent this so-called "tyranny." Thus the lack of representation highlighted by Barber is not really the right for citizens to elect their own representatives - as was the case with the Boston colonists - but rather to have certain positions represented through them.

The use of historical narratives to link one's candidacy to poignant events and figures has been alluded to in a New York Times article. Eckholm (2011) describes the efforts of a selfeducated historical advisor of conservative presidential aspirants and Tea Party candidates. The article states that this self-taught historian uses elements of US history to remake its future, although some academics suggest that his version of history contains significant distortions and partial truths. Barber's particular (mis)appropriation of history in the service of his historical coherence as a candidate is therefore not entirely individual or idiosyncratic. By appropriating or 
misappropriating the name of the historical narrative of the Boston Tea Party, Barber alludes to modern governmental tyranny and lack of representation.

\section{Preempting charges of lack of coherence and preventing threats to freedom}

By drawing on images and tropes of popular historical figures, these multimodal techniques construct continuity while also preempting potential charges of a lack of historical coherence. In a political commercial, anticipating such threats is important, since it is a largely unidirectional medium with limited opportunities to engage with the audience and employ facesaving repair strategies (cf. Goffman, 1967; Brown and Levinson, 1987). For example, in the case of the super PAC's video supporting Hillary Clinton's 2016 candidacy, the cinematography and editing along with the working-class/cowboy imagery preempt a charge of lack of historical coherence associated with gender stereotypes by using a male voice, a cowboy archetype, and associated working-class symbols to show that a strong, working-class man can literally "smash a ceiling" for Hillary and usher her into the role of first female US president. This endorsement by a cowboy — the archetypal trope of the white, working-class male — is significant because Clinton had been said to not appeal to that demographic. Since the narrative of the first female presidency has not yet been written, both the images shown and the words connect Hillary with the cowboy's wife and daughter — making Clinton relatable — but also show her in front of the US military, thereby driving home the point that this is a very American story: Hillary Clinton is a caring, family-woman as well as a leader and a fighter. The notion that she cares for her family is introduced to preempt ultimately double-binding sexist charges that she is simultaneously too feminist, yet not feminine enough to be a leader and a fighter.

Therefore, placing the candidate into the historical narrative makes relevant parallels between historical restrictions of the past and present. The next section looks more closely at 
how the commercials construct a historical narrative preempting potential contradictions to coherence and placing the candidate in a battle against oppression.

\section{Freedom secured by revolution or rebellion}

The second Rick Barber advertisement entitled "Slavery" appeals to a notion of freedom that can be secured by revolution. One can debate whether dedicating a long segment to the nuances of Whiskey Act of 1791 services the frame of freedom for Barber, but through a closer look at Barber's language one can see several relevant features present. Any charge of contradiction made toward a candidate has the potential to undermine her/his coherence. Therefore, Barber preempts a charge of lack of historical coherence by introducing this particular historical event and aligning his views with those of the first US President, George Washington. Washington quelled the Whiskey Rebellion in Pennsylvania, which was a protest to a tax on farmers who used their leftover grains to profit from the distillation and sale of whiskey. Barber presents his own ideas on taxation as legitimate because he argues that the Whiskey Tax was an excise tax used to fund national war; logically, citizens should revolt against taxation unless the taxes they pay are used for a what he calls in Line 1 a "legitimate function of the government," such as funding war.

Barber goes on to contrast this event with new forms of taxation in the contemporary United States. In the first moments of this commercial, Barber repeats the word "tyrannical," also used in the first commercial. He uses the adjective to modify "health care bill" (in the previous commercial he said the IRS would cram health insurance down "our" throats, or else): "Mr. President, some argue that you would have been in favor of this tyrannical health care bill because you enforced the Whiskey Act of 1791. But, that was an excise tax levied to service the military debt incurred by the Revolutionary War, a legitimate function of government, correct?" 
Barber qualifies George Washington's historical quelling of the Whiskey Rebellion by employing the contrastive connective "but." The purpose of the whiskey tax was to fund Revolutionary War debts, a "legitimate function of government"-by contrast with the putatively-illegitimate health care bill. Through this discourse, Barber implies that he and George Washington are like-minded politicians.

The background audio of both of Barber's commercials also resonates with this narrative construction in which there is a "battle" for rights continuing from past to present. Persistent drum beats sound throughout both commercials. Historically, the military drummer guided the actions of troops. Troops were to stop what they were doing and re-group around their commander (Barty-King, 1988). Therefore, the drumming sounds reinforce the notion of freedom secured by war.

In this same segment, Barber furthers his narrative of freedom secured by rebellion or revolution. The mise-en-scène elements coupled with abrupt editing assist Barber in driving his point home. He sits at a table adorned with the Gadsden flag bearing the phrase: "Don't Tread on Me.” This flag has been unofficially adopted by the Tea Party. It is associated with the United States Marine Corp (as was mentioned previously, Barber was a marine). The image of the flag was allegedly painted on drums carried by marines intercepting British ships during the time of the American Revolution. This sequence is accompanied by props such as a Bible, the US Constitution, and a pistol. As soon as Barber starts to speak, there is a jump cut to a pistol. (See Figure 6.) The presence of the pistol and the decision to devote advertising time to its ominous presence further contributes to the idea of continuing the Revolution.

Barber's conversation with a character portraying historical US president Abraham Lincoln exposes the notion of freedom within which he is operating. If freedom is a "marvel of 
metaphorical thought" (Lakoff, 2006: 29) that can be evoked by its opposites, the visage of Lincoln. (See Figure 7) is strongly associated with the Emancipation Proclamation, the executive order issued by Lincoln during the Civil War freeing more than three million slaves (Foner, 2010).

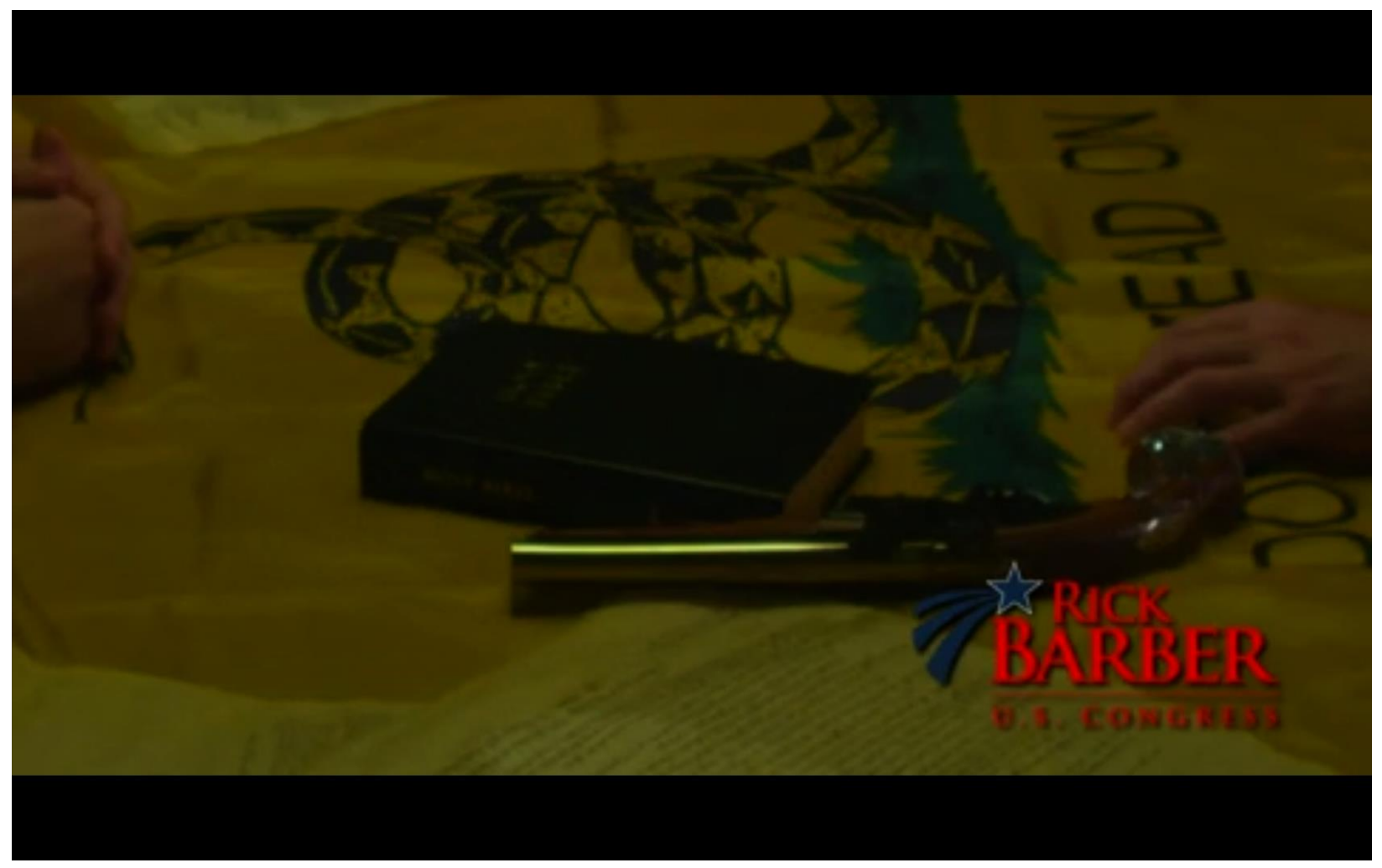

Figure 6. In Barber's "Slavery" advertisement, at the moment that the candidate begins to speak, the camera cuts to a revolutionary era pistol on the table next to a copy of the Bible. The table is adorned with the Gadsden flag.

Note. From "Slavery” by Rick Barber for Congress.

In line 4, when Barber asks the questions "if someone is FORCED to work for months to pay taxes so that a total stranger can get a free meal, medical procedure or a bailout, what's that called? What's it called when one man is forced to work for another?" Here again, the video makes substantial use of jarring jump cuts. (See Figure 8.) Barber's language in conjunction with the cuts emphasize the word "forced." The metaphorical idea of freedom bears within it two 
distinct but related meanings: access, and the absence of impediments. Lakoff (2006: 30) calls this distinction “freedom from and freedom to." Lincoln's answer to Barber in line 5 is “SLAVERY.” Barber's assertion links potential tax increases and a more comprehensive

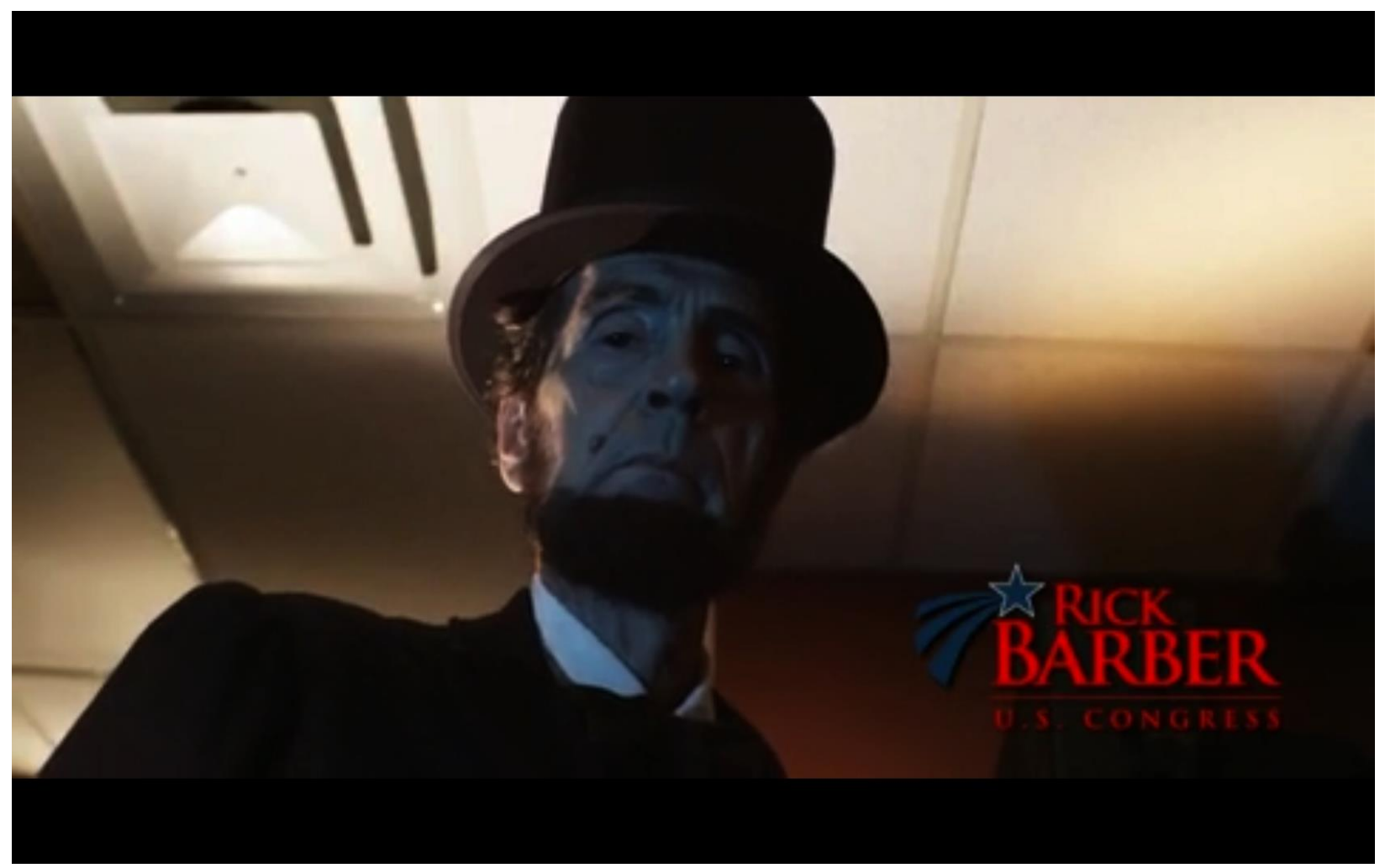

Figure 7. Barber includes the visage of President Abraham Lincoln, the architect of the Emancipation Proclamation, in which 3.1 million slaves were proclaimed free.

Note. From "Slavery” by Rick Barber for Congress.

healthcare bill to the type of slavery that Lincoln abolished and thereby positions himself within an emancipation narrative.

When the Lincoln character says the word "slavery," the sound is accompanied by an intense echo effect. Then, a montage of eight images of slavery is flashed on the screen quickly and consecutively, for instance emaciated Holocaust victims in Nazi concentration camp Buchenwald and at the gate of a Nazi labor camp Dachau in Bavaria. The gate reads "Arbeit Macht Frei," or "work will make you free," the infamous slogan written in German often 
adorning the entrances of Nazi concentration camps. (See Figure 9.) These images are flashed to the rhythm of the always-accompanying drums.
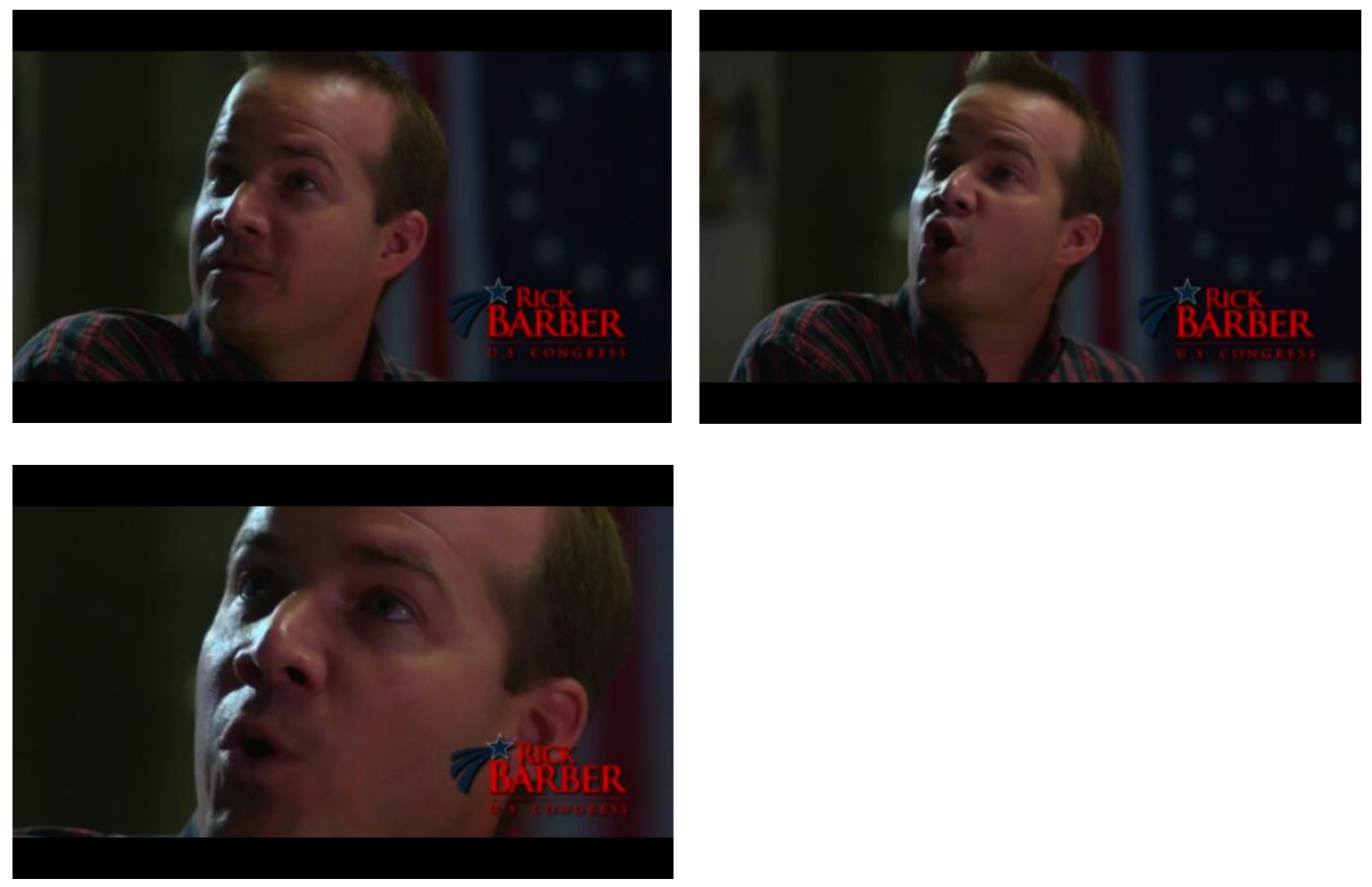

Figure 8. The advertisement uses jarring jump cuts to emphasize the word "forced" as the candidate addresses the Lincoln character.

Note. From "Slavery” by Rick Barber for Congress.

This montage creates an association between unbridled economic competition and human rights, thereby conflating two different notions of freedom. On one hand, the freedom to compete is presented through a lens of resource scarcity where the losers are precluded from accessing resources. On the other hand, freedom is also associated with human rights to eat, drink, sleep, sit, etc. (Lakoff, 2006). The narrative references the former type of economic freedom while the images deal with the latter, more fundamental type of freedom. As a device of historical coherence, the slavery montage equates the freedom to compete economically with inalienable human rights. 

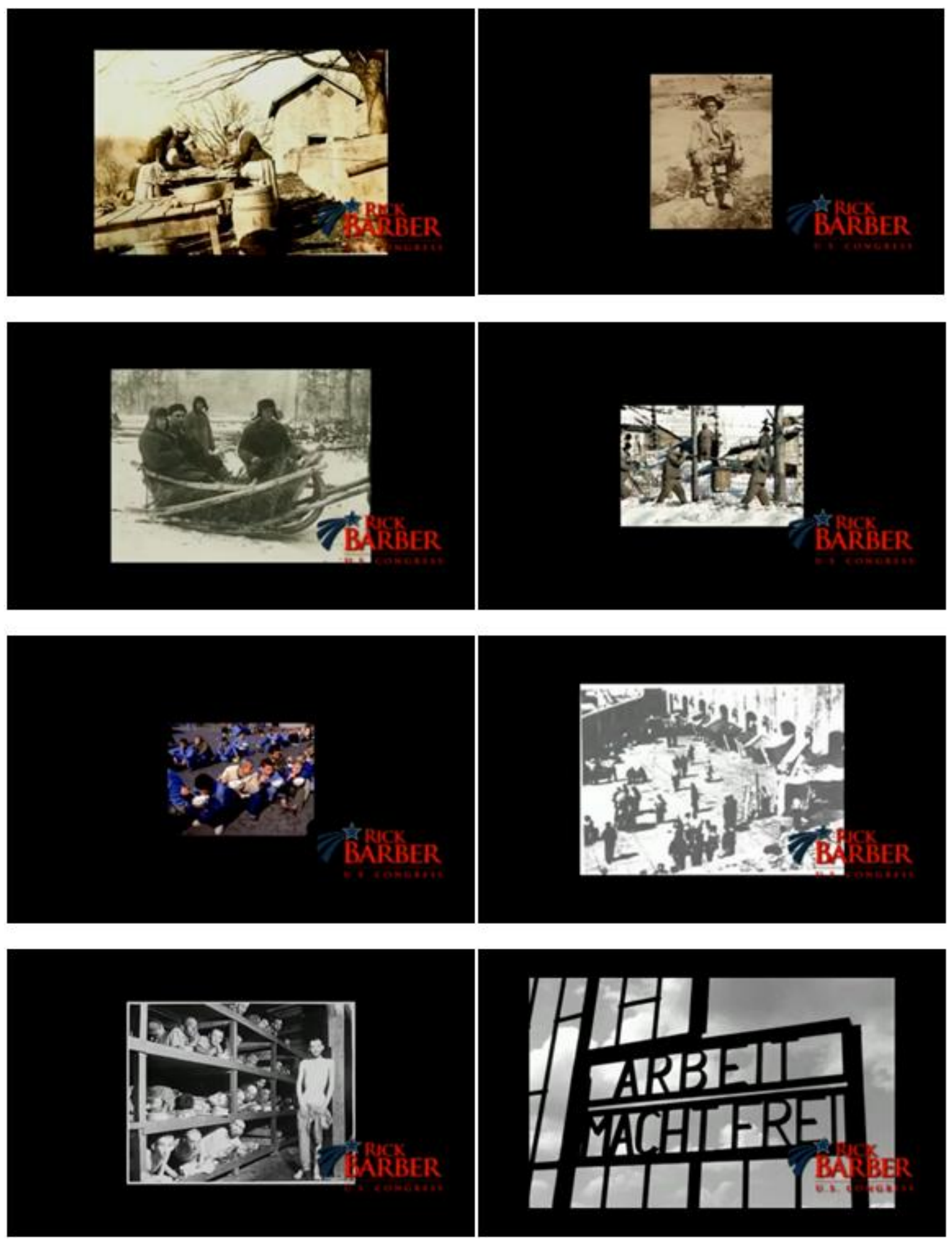

Figure 9. Montage of slavery images.

Note. From "Slavery” by Rick Barber for Congress. 
The long road to mitigating negative gender restrictions.

Freedom from gender restrictions has been more ambiguous for the candidate featured in the second commercial. Throughout her 2008 presidential campaign, Hillary Clinton struggled against the idea that gender might be central to her bid for the presidency (Goldenberg, April 15, 2015). Ironically, she perhaps embraced it most when she conceded the 2008 democratic nomination to Barack Obama:

Although we were not able to shatter that highest and hardest glass ceiling this time, thanks to you it has 18 million cracks in it, and the light is shining through like never before, filling us all with the hope and the sure knowledge that the path will be a little easier next time. (Milbank, June 8, 2008)

Her campaign may have viewed gender as a liability. She ran as an establishment candidate who emerged in a gendered double-bind dilemma: "too conventional to tap into that yearning for change and yet — despite ... effort to seem like just one of the guys — subjected to the most outrageous sexist abuse" (Goldenberg, April 15, 2015). In one example standing out amongst many, a super PAC called "Citizens United Not Timid, (CUNT)," opposed Hillary Clinton's candidacy: “Its logo was a red, white, and blue drawing shaped like a woman's crotch with the tagline, "Citizens United Not Timid" to educate the public about "what Hillary Clinton really is"” (Anderson, 2011: 341).

But as Clinton appeared on the 2016 election landscape, she began to highlight the struggles with sexism endured by women. Introduced before 5,000 female leaders in Silicon Valley’s technology industry in early 2015 by Intel President Renée James as a “modern day suffragette," Clinton spoke of her personal experiences as the only female partner in a law firm with no maternity leave and declared now the time to "crack every last glass ceiling" (Rucker, February 24, 2015). "Suffragette," the term used to describe Clinton, is steeped in its English language etymology - a diminutive label from French directed at militant campaigners for 
women's voting rights that feminists later reclaimed (Cameron, August 15, 2015). During her final presidential debate, as she did when she accepted the democratic nomination for President, Clinton would don "suffragette white," the color worn early in the women's suffrage movement to show group coherence.

In this setting, the super PAC Stand with Hillary released its commercial of the same name. The cowboy crooner/spokesperson featured in the commercial (who incidentally is an actor and not the real singer) starts the commercial by highlighting gender and class: "Looking back in time, learning hindsight's always right. We came together in '08, a defining moment we all can celebrate. And now it's 20-16 and this time I'm a-thinking: Guys, put your boots on and let's smash this ceiling."

The commercial highlights freedom from the ultimate glass ceiling (the US presidency) and the double-binding, sexist interpretations that may have marred Hillary Clinton's '08 campaign. Whereas the "glass ceiling" is typically known as a problem for women advancing in white-collar employment and executive positions, the commercial connects this concept with blue-collar men's work in a frame of freedom. Blue-collar men are literally called to "put ... [their] boots on" and smash the glass ceiling, linking this metaphor with the expansion of freedom - and in the present example, the freedom to be seriously considered for president, despite one's gender. (See Figure 10).

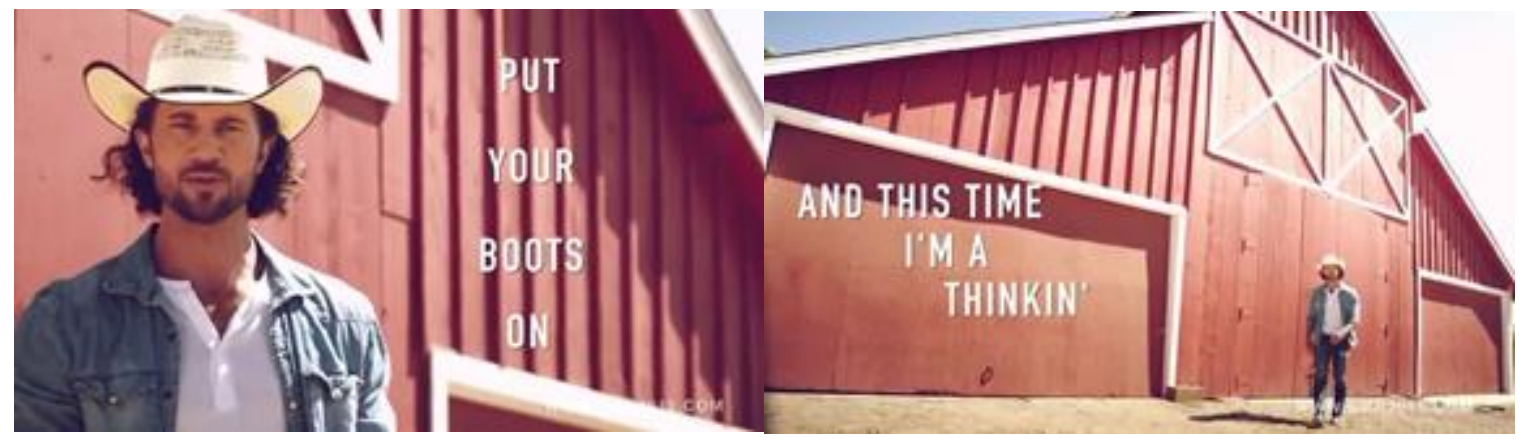




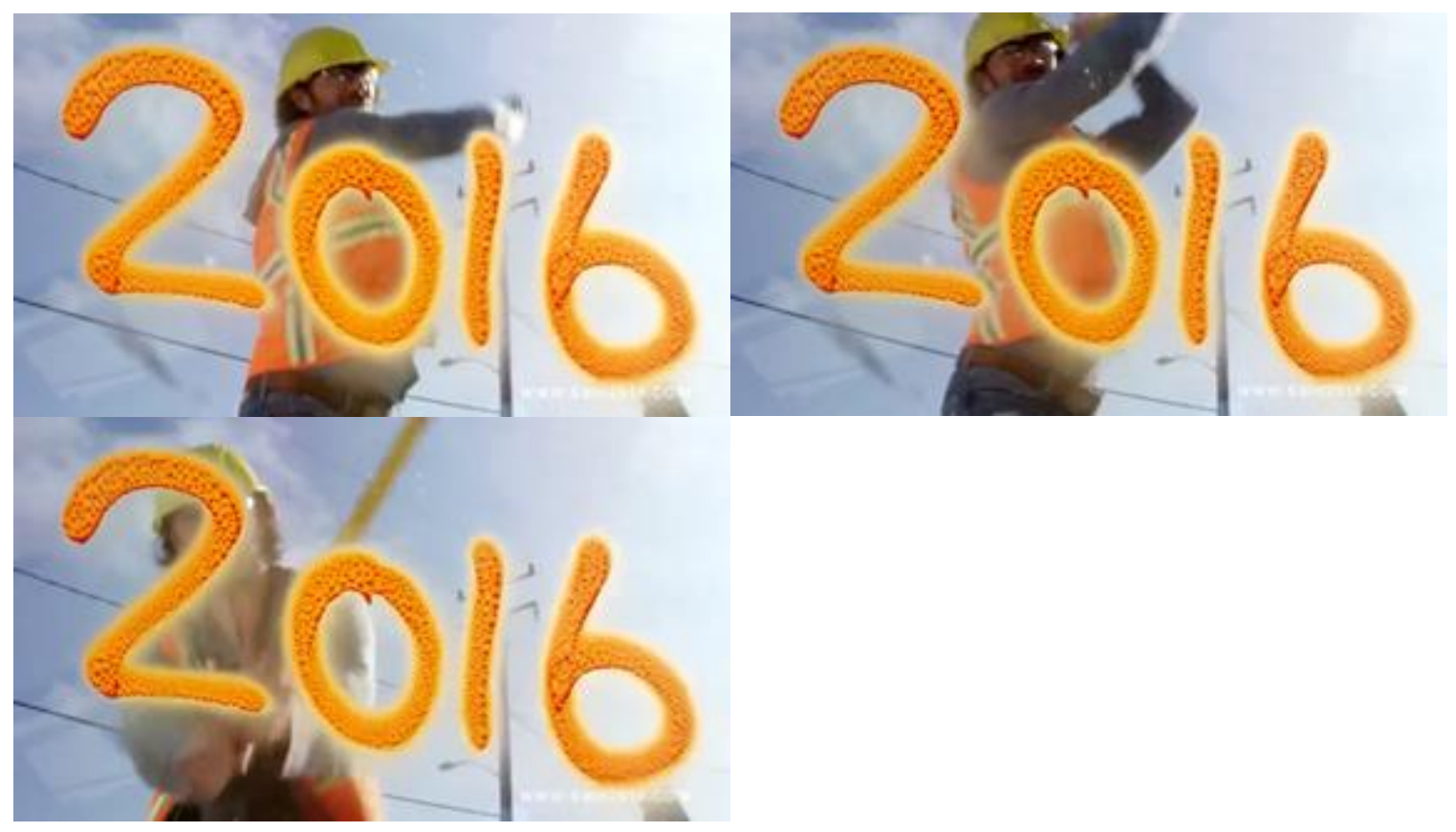

Figure 10. This sequence shows the cowboy by a barn and later in construction attire-workingclass symbols; yet he leads the charge to break the ultimate glass ceiling: the US presidency for this potential female president.

Note. From "Stand with Hillary" by Stand With Hillary 2016

If the viewer doubts the connection to gender relations, the commercial and corresponding lyrics show the cowboy's connection with his family: "I been thinkin' about one great lady like the women in my life." The simile with the use of the word "like" along with the associated image reminds us that this freedom is not just reserved for Hillary Clinton. It extends to the wife and child of the cowboy. The jump cut to the image of the cowboy's wife and daughter drive home the point. (See Figure 11). This issue of freedom from the "glass ceiling" is not just about Hillary Clinton. It is about securing a future for one's family. The commercial challenges the viewer: If you care about your child, you want her to be treated fairly. 


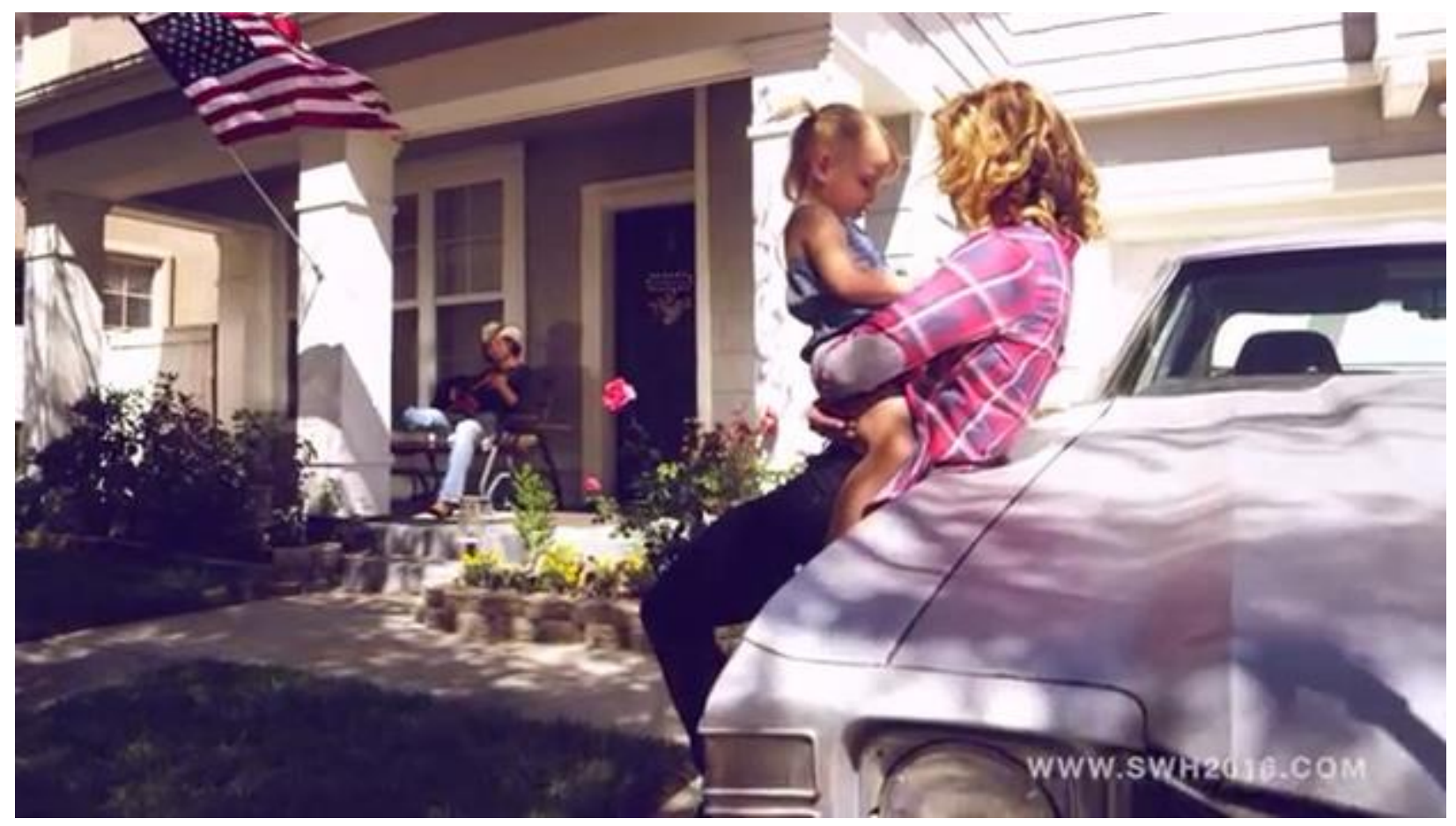

Figure 11. "Stand with Hillary" emphasizes a general freedom from the glass ceiling and the double-binding gender norms through the use of the simile "one great lady like the women in my life" connected by a jump cut to an image the cowboy's daughter.

Note. From "Stand with Hillary" by Stand With Hillary 2016

The music and mise-en-scène elements invite the viewer to entertain this idea that a frontier of gender freedom is a patriotic, American idea: The use of the red, white, and blue motif throughout, the deployment of the US flag, the images of the a picnic seemingly on Independence Day replete with sparklers, and the choice to deliver this message through a country song sung by a cowboy. The narrative constructs a history waiting to be made: The American narrative is not complete without extending freedom to women.

Hillary Clinton used this same brand of historical coherence in her introductory speech at the first 2016 Democratic debate: “And I will do everything I can to heal the divides ... yes, finally, fathers will be able to say to their daughters, you, too, can grow up to be president." She 
reminds voters, and in particular male voters, that her candidacy offers hope that their daughters can grow up in a more egalitarian country.

On her Twitter account, Clinton even relates current policy dynamics around the Affordable Healthcare Act to gender issues, placing her own gender at the center of issues of freedom and progress: "The Affordable Healthcare Act helps millions of Americans. We should build on that progress — not go back to square one." She follows the quote with a red, white, and blue meme that says, "47 million women get preventative healthcare without a copay thanks to the ACA. I'm one of them." (See Figure 12).

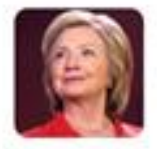

\section{Hillary Clinton}

(c) HillaryClinton

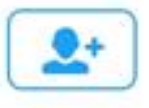

\section{The Affordable Care Act helps millions of Americans. We should build on that progress - not go back to square one.}

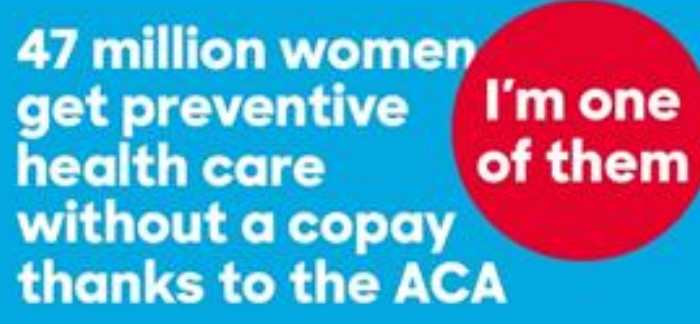

$11 / 18 / 15,7: 52 \mathrm{AM}$

Figure 12. On her Twitter account, Hillary Clinton relates Affordable Healthcare Act policy dynamics to gender issues, placing gender at the center of freedom and progress. 
In these examples, historical coherence is constructed through multimodal techniques drawing on historical language, images, and figures. In doing so, the narrative of a candidate's run for office is presented as intelligible in a larger narrative of political history. More importantly, the historical characters and situations presented are difficult to argue with-they are iconic and associated with deeply-held political values in the US. Thus, by aligning candidates with these iconic images, commercials justify their candidates, preempt potential ideological contradictions, and tell a story in which these candidates are fighting for freedom (and will continue to do so in the future). In the next section we consider the limitations, implications, and future directions of these results.

\section{Discussion and conclusion}

Through an analysis of commercials produced by Alabama Congressional Tea Party candidate Rick Barber and by the Stand with Hillary super PAC, this paper has argued that political commercials make use of narrative strategies to create "existential coherence" (Duranti, 2006: 490) for candidates. In the case of Barber, the candidate presents his decision to run for office as a logical extension of the other work he has done in his life, thereby emphasizing consistency with who he is. The commercial featuring Hillary Clinton shows the candidate as a caring family woman who will not threaten the masculinity of a male archetype like the cowboy, and also as a strong, active person. This paper extends Duranti's (2006) work about narrating the political self to argue that political speech may also present candidates' decisions to run for office as an extension of history by presenting narratives congruent with those of important historical figures and events, thereby generating "historical coherence".

In Barber's videos, the candidate advances his narrative of historical coherence by conflating two distinct types of freedom: the freedom to be economically competitive, and the 
freedom of human rights. The advertisements couple his language with poignant historical images, mise-en-scène, and video-style techniques. The advertisements aid the candidate's presentation of himself in this manner by contributing embodied actions (pointing and finger tapping), sound (echo effects, raising volume, repetitive drum beats reminiscent of the Revolutionary War), cinematography (jump cuts, abrupt cuts, hand-held camera motion), the use of Soviet montage techniques (in the slavery montage), and props and other mise-en-scène elements such as a revolutionary era pistol, the US Constitution, the Bible, the US flag, the Gadsden flag, and actors portraying beloved historical figures from both the American Revolution and the Civil War eras.

In the commercial advocating Hillary Clinton, freedom and progress is reconciled by directly addressing the competing discourses of masculinity and femininity to construct a coherent leader who appeals to a particular potential voter base. Freedom is framed in a constrained way, as consistent with legible historical narratives such as women's rights wherein woman sought legal rights, yet still maintained domestic duties. This historical narrative contrasts with more radical notions of progress that might more directly challenge traditional gender roles. This resonance between proposing something so different as a female president, and the women's right movements of the past, is achieved through images that retain or cue traditional gender roles (e.g., white, idyllic, semi-rural family life).

With recent developments in US politics such as the emergence of the Tea Party and the election of the first African-American President, future research may investigate whether or not candidates' presentations of themselves are undergoing a shift in narrative. Is there precedence for adhering to particular historical narratives in candidates' presentations of themselves? Do 
certain candidates gain more traction by linking themselves with particular versions of history, certain types of freedom, or with historical figures or archetypes?

For example, during the second 2016 Republican Debate, presidential candidate and retired neurosurgeon Ben Carson linked his narrative of past democratic political affiliations with the deceased Republican icon, President Ronald Reagan. Like Carson, Reagan was a Democrat before switching to the Republican Party. Much like how Alabama Congressional candidate Rick Barber connected his narrative with those of the founding fathers, Carson makes his partisan switch coherent by linking it up with Reagan's switch to the Republican party in 1962: “I was a radical Democrat before I started listening to Ronald Reagan. And he didn't sound like what they said Republicans were. He sounded logical. And I hope that I sound logical also.”

Recently-elected US President Donald Trump makes for an interesting test case for existential and historical coherence. Existentially, his campaign discourse focused on his candidacy as a direct extension of his business experience and personal qualities. To buttress this narrative, he told stories about deals he made in the past as evidence for his readiness for office. Historically, the continuity is often implicit. The slogan "make America great again" and similar refrains throughout suggest nostalgia for a recoverable past, in a way resurrecting a lost coherence. However, Trump too has called on historical figures and their actions as continuous with his own, like during a rally in Florida when he addressed the "fake news" phenomenon by aligning himself with Thomas Jefferson, Andrew Jackson, and Abraham Lincoln who "fought with the media and called them out often times on their lies." (He mentioned these historical figures about a month after his inauguration rather than during his campaign). ${ }^{2}$

\footnotetext{
${ }^{2}$ http://www.whatthefolly.com/2015/06/16/transcript-donald-trumps-presidential-campaign-announcement-speechpart-1/; http://www.palmbeachpost.com/news/national/read-full-transcript-trump-rally-speechflorida/DeDCpoNEKLQmWcIKndWB0M/
} 
This paper provides a foundation for future discussions about existential coherence and historical coherence, as well as multimodality in political discourse. We propose that this type of analysis can be conducted with regard to diverse political discourse and should look beyond language to recognize and analyze the multimodal discourse used in the presentation of candidates' narratives. 


\section{References}

Anderson, K (2011) "Rhymes with Blunt" Pornification and US Political Culture. Rhetoric and Public Affairs, 14(2): 327-368.

Barber for Congress (2010, June 27) Slavery: Rick Barber for Congress. Retrieved October 20, 2011 from http://www.youtube.com/watch?v=kn14RwuJJRg

Barber for Congress (2010, June 13) Gather Your Armies: Rick Barber for Congress. Retrieved October 20, 2011 from http://www.youtube.com/watch?v=6iQ7ZDUutU4

Barthes, R (1964/1968) Elements of semiology. New York: Hill and Wang.

Barthes, R (1957/1972) Mythologies. New York: Harper Collins.

Barty-King, H (1988) The Drum: A Royal Tournament Tribute to the Military Drum. London: Royal Tournament.

Ben Wekesa, N (2012) Cartoons can talk? Visual analysis of cartoons on the 2007/2008 postelection violence in Kenya: a visual argumentation approach. Discourse and Communication, 6(1): 223-238.

Brown, P and Levinson, S (1987) Politeness: Some Universals in Language Use. Cambridge: Cambridge University Press.

Cameron, D (2015, August 15) Ette-ymology. Language: A Feminist Guide. Retrieved from https://debuk.wordpress.com/2015/08/16/ette-ymology/

Corrigan, T (2011) A Short Guide to Writing About Film. New York: Longman.

Confesssore, N and Lichtblau, E (2015, May 17) 'Campaigns' Aren’t Necessarily Campaigns in the Age of 'Super PACs.' The New York Times. Retrieved from http://www.nytimes.com/ 2015/05/18/us/politics/super-pacs-are-remaking-16-campaigns-official-or-not.html?_r=0

Duranti, A (2006) Narrating the political self in a campaign for US Congress. Language in Society 35(4): 467-497.

Eckholm, E (2011) Using history to mold ideas on the Right. The New York Times, 4 May 2011. 
Retrieved from http://www.nytimes.com/2011/05/05/us/politics/05barton.html

Eisenstein, S (1949) Film Form: Essays in Film Theory. New York: Hartcourt.

Fairclough, N (1998) Media Discourse. New York: Bloomsbury.

Foner, E (2010) The Fiery Trial: Abraham Lincoln and American Slavery. New York: W.W. Norton and Company.

Goffman, E (1967) Interaction Ritual: Essays on Face-to-Face Behavior. Chicago: Aldine Publishing.

Goldenberg, S (2015, April 15) Clinton returns to smash glass ceiling, with gender at forefront of campaign. The Guardian. Retrieved from http://www.theguardian.com/usnews/2015/apr/12/hillary-clinton-2016-presidential-campaign-strategy-politics

Goodwin, C (2007) Language, culture, social organization and the material word: Why a five field approach is necessary. Teaching Anthropology: SACC Notes, 13: 5-9.

Graham, D (2015). Super PACs are for republicans, campaign Cash is for democrats. The Atlantic, 15 July 2015. Retrieved from http://www.theatlantic.com/politics/ archive/2015/07/super-pacs-are-for-republicans-campaign-cash-is-for-democrats/398759/

Gramsci, A (1971/2010) Selections from the Prison Notebooks. New York: International Publishers.

Kaid, L (2006) Political advertising in the United States. In: Kaid L and Holtz-Bacha C (eds), The Sage Handbook of Political Advertising. Thousand Oaks: Sage, pp.37-61.

Kaid, L and Davidson, D (1986) Elements of videostyle: candidate presentation through television advertising. In: Kaid, L, Nimmo, D and Sanders, K (eds), New Perspectives on Political Advertising. Carbondale: Southern Illinois Press, pp.184-209.

Kress, G (2009) What is mode? In: Jewitt C (ed) The Routledge Handbook of Multimodal Analysis. New York: Routledge, pp.184-209. 
Kress, G and Van Leeuwen, T (2001) Multimodal Discourse: The Modes and Media of Contemporary Communication. London: Arnold Press.

Lakoff, G (2006) Whose Freedom? The Battle Over America's Most Important Idea. New York: Farrar, Straus, and Giroux.

Labaree, B (1979) The Boston Tea Party. Boston: Northeastern University Press.

McLeod, D, Kosicki, G, and McLeod, J (2009) Political communication effects. In: Bryant J and Oliver MB (eds), Media Effects: Advances in Theory and Research. New York: Routledge, pp. 228-251.

Milbank, D (2008, June 8) A Thank-You for 18 Million Cracks in the Glass Ceiling The Washington Post. Retrieved from http://www.washingtonpost.com/wpdyn/content/article/2008/06/07/AR2008060701879.html

Norris, S (2004) Analyzing Multimodal Interaction: A Methodological Framework. New York: Routledge.

Ochs, E (1979) Transcription as theory. In: Ochs E and Schieffelin B (eds), Developmental Pragmatics. New York: Academic Press, pp. 43-72.

Rucker, P (2015, February 24). Clinton: 'Crack every glass ceiling.' The Washington Post. Retrieved from http://www.washingtonpost.com/politics/hillary-clinton-previews-2016says-its-time-to-crack-every-last-glass-ceiling/2015/02/24/c5d262c2-bc45-11e4-86684e7ba8439ca6_story.html

Sacks, H, Schegloff, E, and Jefferson, G (1974) A simplest systematics for the organization of turn-taking for conversation. Language 50: 696-735.

Silverstein, M (2001) The message "message in the political battle. Language and Communication 31(3): 203-216.

Stand with Hillary. (2014, November 16). Stand with Hillary. Retrieved from February 15, 2015 
https://www.youtube.com/watch?v=rfU3hI8ML30

Taylor, C (1991) The dialogical self. In Hiley D, Bohrman J, and Shusterman R (eds), The interpretive turn: philosophy, science, culture. Ithaca, NY: Cornell University Press, pp. 304-314.

Unsworth, L and Cléirigh, C (2009) Multimodality and reading: the construction of meaning through image-text interaction. In: Jewitt C (ed), The Routledge Handbook of Multimodal Analysis. New York: Routledge, pp. 151-163.

Van Dijk, TA (1997) What is political discourse analysis. Belgian journal of linguistics 11(1): $11-52$.

Van Dijk, TA (1980) Text and context: Explorations in the semantics and pragmatics of discourse. London: Longman.

Van Gijsel, S, Geeraerts, D, and Speelman, D (2004) A functional analysis of the linguistic variation in Flemish spoken commercials. Journées Internationales d'Analyse Statistique des Données Textuelles 7: 1136-1144.

Vesnic-Alujevic, L (2011) Communicating with voters by blogs? Campaigning for the 2009 European Parliament elections. Discourse and Communication 5(4): 413-428. 


\section{Appendix A}

\section{Transcription Conventions}

(Language transcriptions based off of Sacks, Schegloff and Jefferson, 1974)

Rick Barber: The name of the speaker is separated from the text by a colon (:) and one space

A TEA TAX!! Capital letters indicate high volume

Ga::ther yo::ur armies A colon (:) stands for the lengthening of sound

A number in brackets indicates a timed pause

((laughter)) Double parentheses denotes context or embodied practices that accompanies the talk

$=\quad$ An equals sign (=) stands for latching, meaning that there is not a space between the two utterances

Omitted part of the transcript for brevity

\section{Video-Style Transcription Conventions}

MS

Medium shot (between a close-up and a full shot; shows most, but not all of the figure)

$\mathrm{CU}$

Close-up (shows only a part of a figure of a space e.g. a shot of the head)

ECU Extreme close-up (shows a part of the figure or the space in great detail

e.g. a shot of an eye)

MCU

Medium close-up

LS

Long shot (shows entire figure in space, placing it within in its surroundings)

OHS

Overhead shot (the point of view is directly above the action) 
abrupt or jarring fashion)

TRS

Tracking shot (the point of view moves or follows a figure, such as on a dolly)

PN

Pan (Point of view moves from left to right or right to left)

HA

High-angle (the point of view is above and looking downward)

FO

Fade-out (a gradual transitions from one image to another featuring a dissolve)

LA

Low-angle (the point of view is below and looking upward)

ZI

Zoom in (the camera moves in from a shot that is farther away to one that is closer)

$\mathrm{ZO}$

Zoom out (the camera moves out from a shot that is closer to one that is farther) 


\section{Appendix B}

Transcript

Full transcripts available upon request. For the sake of brevity, only the transcript portions included in the paper are documented below.

Video 1: Gather Your Armies (1:03)

http://www.youtube.com/watch?v=6iQ7ZDUutU4

\begin{tabular}{|c|c|}
\hline Verbal & Video Analysis and Embodiment \\
\hline & Repetitive drum beat, a march, accompanies entire sequence \\
\hline $\begin{array}{l}2 \text { And if that's not enough - } \\
\text { some of your men own } \\
\text { taverns. Sam, you were a } \\
\text { brewer; Mr. President, a } \\
\text { distiller. You know how tough } \\
\text { it is to run a small business } \\
\text { =without a tyrannical } \\
\text { government on your back.= }\end{array}$ & $\begin{array}{l}2 \text { TRS from above. Lights and furniture. MS of white balding male facing } \\
\text { other white men at a table who wear revolutionary era attire. Speaker } \\
\text { wears a red and blue plaid button-down shirt with a white undershirt } \\
\text { sticking out. Looks left and motions with left hand towards a character } \\
\text { named "Sam"; looks to the right while addressing "Mr. President". } \\
\text { Moves head from left to right as if speaking to more than one person. } \\
\text { Hand held camera motion. Fast CT to facial close up. Fast CT to MS. } \\
\text { Hand held camera zooms in on candidate's face. CT back to a MS. }\end{array}$ \\
\hline $\begin{array}{l}3 \text { Today, we have an internal } \\
\text { revenue service that enforces } \\
\text { what they call a progressive } \\
\text { income tax. }\end{array}$ & 3 MS JCT to CU when candidate says "they". \\
\hline $\begin{array}{l}4 \text { You'll love this. Every year, if } \\
\text { not every quarter, we're } \\
\text { basically required to spy on } \\
\text { ourselves. }\end{array}$ & $\begin{array}{l}4 \mathrm{CT} \text { from } \mathrm{CU} \text { to } \mathrm{MS} \text { to } \mathrm{ECU} \text { to an ECU of the eye of a character } \\
\text { representing Ben Franklin. All JCTs. }\end{array}$ \\
\hline $\begin{array}{l}6 \text { Without representation they } \\
\text { could increase taxes, add } \\
\text { costly regulations, or perform } \\
\text { malicious audits. }\end{array}$ & $\begin{array}{l}6 \mathrm{CT} \text { back to MS of candidate over the shoulder of out-of-focus } \\
\text { revolutionary figure. When candidate says "perform malicious audits" } \\
\text { camera pans to mise-en-scène elements on table and focuses on } \\
\text { revolutionary era pistol on table. Next to gun, the camera PN to MCU of } \\
\text { a hand costumed in revolutionary attire, impatiently tapping fingers. }\end{array}$ \\
\hline$\cdots$ & $\cdots$ \\
\hline
\end{tabular}




\begin{tabular}{|l|l|}
\hline $\begin{array}{l}\text { 8 Now I took an oath to } \\
\text { defend that with my life. And I } \\
\text { CAN'T STAND BY WHILE THESE } \\
\text { EVILS ARE PERPETRATED. }\end{array}$ & $\begin{array}{l}\text { 8 PN to MS. Candidate points to document on table and the camera } \\
\text { captures his hand. It is a copy of the US Constitution. Behind it, the } \\
\text { table is covered with the red and white stripes of the US flag. CT to } \\
\text { MCU of candidate as his volume increases. }\end{array}$ \\
$\begin{array}{l}\text { 9 You gentlemen revolted over } \\
\text { a Tea tax - A TEA TAX! NOW } \\
\text { LOOK AT US. }\end{array}$ & $\begin{array}{l}\text { 9 On the word "you", CT to slight HA/MS. There is a group of three men } \\
\text { sitting at a table facing the camera. The candidate sits before them, his } \\
\text { back to the camera. Low-key lighting produces shadows on their faces. } \\
\text { CT to CU of candidate's face as he says "tea tax." CT again to a slight } \\
\text { side view as he repeats "a tea tax!" CT to a frontal CU. As he says "now } \\
\text { look at us." }\end{array}$ \\
\hline ..
\end{tabular}

Video 2: Slavery $(2: 30)$

http://www.youtube.com/watch?v=kn14RwuJJRg

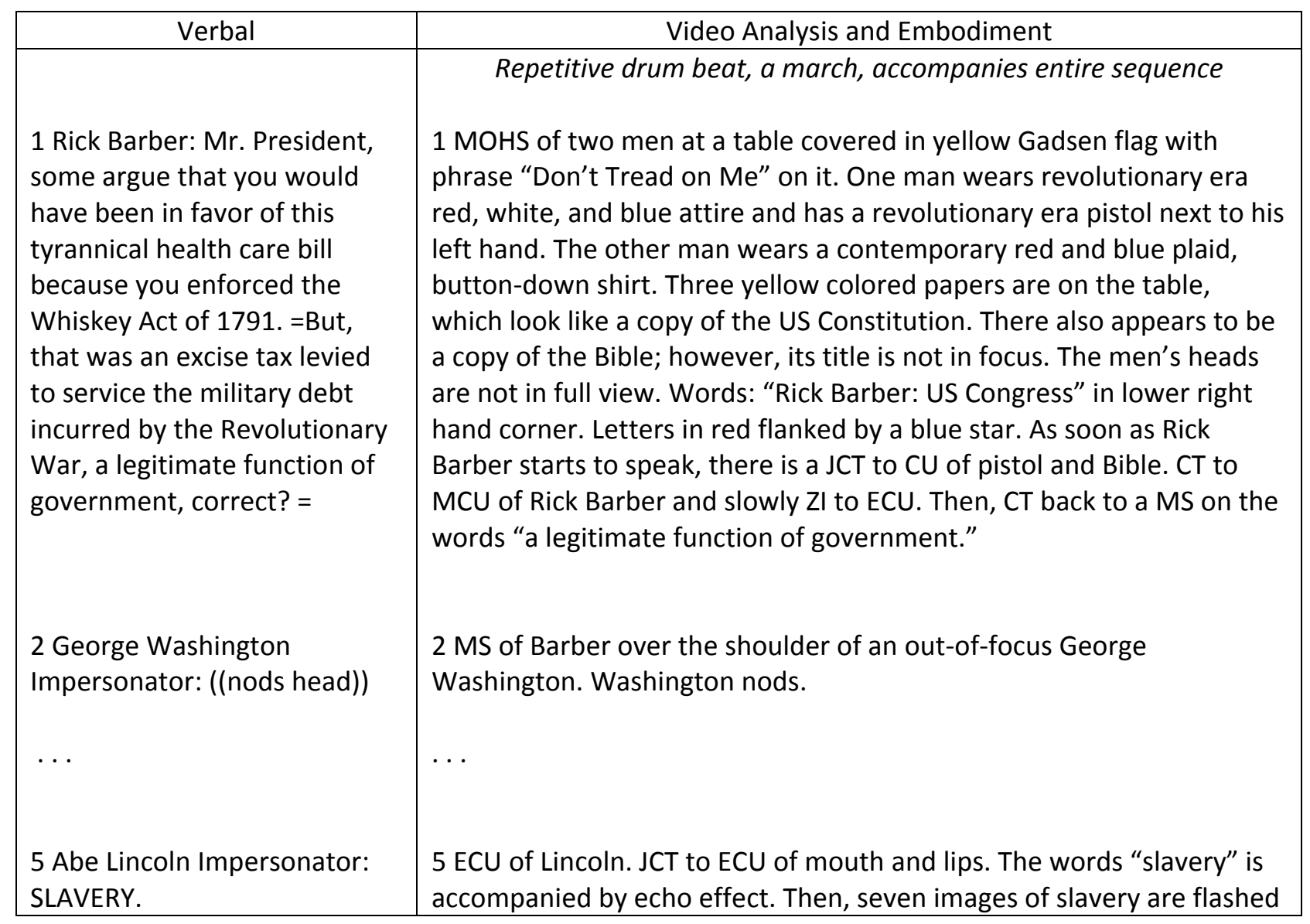




\begin{tabular}{|l|l|}
\hline & $\begin{array}{l}\text { on the screen quickly and consecutively. Possibly: 1) enslaved African } \\
\text { American women; } 2 \text { ) an enslaved African American man; 3) a Soviet } \\
\text { forced labor camp at the time of Stalin; 4) another Soviet forced labor } \\
\text { camp; 5) a Chinese labor camp; 6) emaciated male Holocaust victims in } \\
\text { a Nazi concentration camp; 7) the gate of Nazi labor camp Dachau in } \\
\text { Bavaria. The gate read “Arbeit Macht Frei," the infamous slogan "work } \\
\text { will make you free," known for being placed at the entrances of Nazi } \\
\text { concentration camps. These images are flashed to the rhythm of the } \\
\text { always accompanying drums. }\end{array}$ \\
\hline..
\end{tabular}

Video 3: Stand with Hillary (3:23)

\begin{tabular}{|l|l|}
\hline $\begin{array}{l}\text { 3 Looking back in time, } \\
\text { learning hindsight's always } \\
\text { right. }\end{array}$ & $\begin{array}{l}\text { 3 JCT to MS of profile of cowboy crooning the song lyrics. Select } \\
\text { portions of the lyrics "Learnin' Hindsight's Always Right" appear in } \\
\text { white on the right side of the screen. Camera panning effect (Ken } \\
\text { Burns effect) over an old MS picture of the Clinton family from the } \\
\text { 1990s }\end{array}$ \\
$\begin{array}{l}4 \text { We came together in '08, a } \\
\text { defining moment we all can } \\
\text { celebrate. }\end{array}$ & $\begin{array}{l}\text { SCT to cowboy sitting on a porch playing acoustic guitar on a bench. } \\
\text { Select portions of the lyrics "A Defining Moment" appear in white on } \\
\text { the left side of the screen. JCT to a HA shot of people praying over a } \\
\text { hamburger meal, including cowboy's family. Red, white, and blue } \\
\text { decorations don the table. JCT to MS of two table members passing } \\
\text { food. JCT to MS of cowboy, his wife, and daughter playing with } \\
\text { sparklers. }\end{array}$ \\
$\begin{array}{l}5 \text { And now it's 20-16 and this } \\
\text { time I'm a-thinking: Guys, put } \\
\text { your boots on and let's smash } \\
\text { this ceiling. } \\
\text { great lady like the women in } \\
\text { my life. }\end{array}$ & $\begin{array}{l}5 \text { JCT back to the cowboy standing at the barn. CU of his face in which } \\
\text { he looks directly into the camera. JCT to LG of cowboy walking away } \\
\text { from the barn. Select portions of the lyrics "And This Tie I'm a Thinkin' } \\
\text { Guys" appear in white on the left side of the screen. CU of cowboy } \\
\text { and JCT back to a LS. Select portions of the lyrics "Put Your Boots On" } \\
\text { appear in white on the right side of the screen. JCT back and forth } \\
\text { between cowboy at the barn and a MS of him in construction attire } \\
\text { smashing a glass ceiling that had the number 2016 on it using a } \\
\text { sledgehammer. } \\
6 \text { JCT to cowboy playing in a music group. (All group members wear } \\
\text { cowboy hats and an American flag hangs on the wall.) JCT to image of } \\
\text { CU of cowboy's wife and daughter. }\end{array}$ \\
\hline
\end{tabular}


7 She's a mother, a daughter, and through it all she's a loving wife.

$8 \mathrm{Oh}$, there is something about her ... this great lady. Caring, hard working once a first lady She fights for country -n- my family.

9 Now it's time for us to stand up with Hillary. Hillary. Stand up. With Hillary.

10 Don't matter if you're living across this great land in a red or a blue state.
$7 \mathrm{JT}$ to a brief montage sequence of old photos featuring the Clintons. The first photo shows Hillary and Bill fawning over baby Chelsea. The image is coupled with a Ken Burns' effect version on the image framing behind it. Select portions of the lyrics "She's a Mother, A Daughter" flash in white on the left side of the screen. JCT to the second photo in the sequence: a photo of the young Clinton couple together.

$8 \mathrm{JCT}$ back to the country group and then JT back to the cowboy on the porch sitting on a bench. JCT to ECU of cowboy's head and once again select portions of the lyrics "Caring, Hardworking" appear in white on the right side of the screen. JCT to ECU of cowboy's foot tapping to the rhythm. JCT to cowboy's face in front of the barn. Select portions of the lyrics "She Fights for Country and My Family" appear in white on the right side of the screen. JCT out to a MS of the cowboy in front of the barn.

9 JCTs back and forth between the cowboy in front of the barn in a LA MS and a CU side profile black and white photo of Hillary. The words "Stand With Hillary" scroll across the screen. Fade to the cowboy with his family and then back to him with his country music group.

Assorted JCTs showing the CUs of the band members' hands playing the guitars and then a ZO to the entire band.

10 Fade out to the cowboy standing by the side of a road wearing a red and blue plaid shirt next to his red pick up truck. MCU from the side and then another from behind. He has a gas can, so his truck must have run out of gas. A motorcycle pulls in and the driver is wearing a black helmet. The cowboy tips his hat at the driver. The driver takes her helmet off revealing long, curly blonde hair. She smiles at the cowboy and he smiles back as he gets on the back of her motorcycle. 